\title{
What drives investment bank performance? the role of risk, liquidity and fees prior to and during the crisis.
}

\author{
Emmanuel Mamatzakis ${ }^{1}$ and Theodora Bermpei $^{2}$
}

This paper examines factors that affect the performance of investment banks in the G7 and Switzerland. In particular, we focus on the role of risk, liquidity and investment banking fees. Panel analysis shows that those variables significantly impact upon performance as derived from stochastic frontier analysis (SFA). Given our sample also comprises the financial crisis, we further test for regimes switches using dynamic panel threshold analysis. Results show different underlying regimes, in particular over the financial crisis. In addition, a strong positive effect of Z-Score on performance for banks in the regime of low default risk is reported, whilst fee-income ratio has also a positive impact for banks with low level of fees. On the other hand, liquidity exerts a negative impact. Notably, there is a clear trend of mobility of banks across the two identified threshold regimes with regards to risk a year before the financial crisis. Our results provide evidence that recent regulation reforms regarding capital adequacy and liquidity requirements are on the right track and could enhance performance.

Keywords: Investment Banking, Risk, Liquidity, Fees, Dynamic Panel Threshold Analysis.

JEL classification: D24, G01, G3, G42, L25.

\footnotetext{
${ }^{1}$ Professor of Finance, School of Business, Management and Economics, University of Sussex, Jubilee Building, Brighton, BN1 9SL, United Kingdom. ${ }^{2}$ School of Business, Management and Economics, University of Sussex, Jubilee Building, Brighton, BN1 9SL, United Kingdom.

Corresponding author: Emmanuel Mamatzakis, e.mamatzakis@sussex.ac.uk.
} 


\section{Introduction}

The liberalization and globalization processes resulted in a rapid development of the investment banking industry in all the industrialized countries before the burst of the financial crisis in 2007. Investment banks primarily engage in the issuance of equity or debt securities and in mergers and acquisitions (M\&A) advisory services. In addition, investment banks' activities include trading, securities, and merchant banking and investment management services. The wide operational spectrum of the investment banking industry has significantly increased the importance of these financial institutions for the global financial system.

The high level of financial integration in the first half of the 2000 decade has led to a rapid growth of the investment banking sector, particularly in the G7 and Switzerland, (Tomljanovich and Ying 2005; Morana, 2008; Baglioni et al., 2013). Investment bank presence both in terms of number of institutions and operations is centred in these countries (Kalemli-Ozcan, 2012; Thomson Reuters, 2012). The development of investment banking activities reached its peak in 2006, when the industry's total income in the G7 and Switzerland amounted to 80.67 (US\$bn). In particular, investment banking earnings constituted $62 \%$ of total bank income in the US and $30 \%$ of the gross output of the UK economy in 2006 (Thomson Reuters, 2007; Burgess, 2011). However, this strong growth came to an abrupt end due to the financial crisis in 2007. The investment banking sector in the G7 and Switzerland experienced a considerable deceleration in activity as revenue dropped more than half from its highest point in 2006, reaching a total value of 39.07 (US\$bn) in 2008. The industry as a whole has been profoundly reformed by the turmoil. ${ }^{2}$ The crisis revealed that investment banking activities are highly complex and interconnected (Demirguc-Kunt and Huizinga, 2010; Adrian and Shin, 2010), particularly between US and European investment banks (Eichengreen, 2012). As a consequence the transmission of the US sub-prime mortgage meltdown led to a major recession in the G7 and Switzerland.

In response to the 2007 financial crisis, US regulators passed the Dodd-Frank Act (2010). This Act requires investment banks to have higher capital adequacy ratios as a 'buffer' against credit crunch. Moreover, it includes the 'Volcker Rule' that prohibits

\footnotetext{
${ }^{2}$ To mention but a few events, JPMorgan acquired Bear Stearns with the financial aid of the Federal Reserve Bank, Bank of America merged with Merrill Lynch, while another prominent investment bank, Lehman Brothers, filed for bankruptcy.
} 
'a banking entity to i) engage in proprietary trading; or ii) acquire or retain any equity, partnership, or other ownership interest in or sponsor a hedge fund or a private equity fund' (Dodd-Frank Act, 2010). The Rule consequently aims to separate commercial banking from investment banking that is particularly comprised of proprietary trading. Moreover, the impact of the 'Volcker Rule' implementation is not limited within the US as it also applies to the US subsidiaries of foreign banks. ${ }^{3}$

Despite the importance of the investment banking for the G7 and Switzerland, existing research on investment bank performance determinants is limited, while there is no study that includes the years of the financial crisis. Radic et al. (2012) is the only study to focus exclusively on the performance of investment banks but they cover just the pre-crisis period (2001-2007). The authors estimate profit and cost functions with investment banking fees as output, concluding that insolvency risk has a positive effect on cost inefficiency. Earlier studies, such as those by Allen and Rai (1996) and Vander (2002), examine the performance of universal banks that include investment banking activities. In particular, Allen and Rai (1996) review the efficiency of universal banks compared with conventional banks using both parametric and non-parametric methods. They find that universal banks operate more efficiently than traditional banks. The results of Vander (2002) back this finding of Allen and Rai (1996). A later study by Beccalli (2004) focuses on the performance of non-bank investment firms that engage solely in investment banking activities. Beccalli (2004) performs a comparison study between the UK and Italian investment firms over the 1995 to 1998 period. The author finds that the UK investment firms are more efficient than Italian firms.

Against this background, an examination of the performance determinants of investment banks for a period that includes the financial crisis could be of interest to both bankers and regulators. In this paper we focus on fees, risk and liquidity as drivers of the performance of these institutions. We give emphasis to fees because investment

\footnotetext{
${ }^{3}$ The Rule has given rise to concerns due to its extraterritorial effect on the activity of the non-US banking institutions (Baxter, 2012). Despite the initial opposition of many countries to the formal application of the Rule, countries such as Germany and the UK acknowledge that regulatory amendments should be employed, aiming to rationalize banks' operations in both commercial and investment banking activities. In particular, the UK, France and Germany have been seriously considering the introduction of a regulatory reform similar to the 'Volcker Rule' (Liikanen, 2012; Vickers and Lagarde, 2013; Gambacorta and Van Rixtel, 2013). The widespread criticism of the Rule is further bolstered by the proposition that only US banks should have the right to trade US government bonds. Banks in counties such as Canada, Japan and the UK issue substantial levels of foreign sovereign debt and their exemption from the US government debt market could harm their financial markets.
} 
banks, as opposed to conventional banks, engage primarily on non-interest income operations (Demirguc-Kunt and Huizinga, 2010). This concentration on fee-based operations could increase the risk of investment banks because of the high volatility of earnings stemming from non-interest income operations (Stiroh, 2004 Demirguc-Kunt and Huizinga, 2010). On the contrary, conventional banks can exploit risk diversification benefits (De-Young and Rice, 2004; Chiorazzo et al., 2008). Thus, investigating the impact of default risk on investment bank performance is of vital importance in the context of this study. In addition, investment banks carry higher liquidity risk than commercial banks, as the latter, in case of a financial shock, can count on deposits (Gatev and Strahan, 2006; Gatev et al., 2009). Hence, the level of liquid assets availability could form another important contributing factor to the performance of investment banks, particularly at a period of high liquidity constraints.

This paper contributes to the banking literature in several ways. Firstly, this is the only study on investment bank performance that covers a period (1997-2010) that includes the crisis years. To this end, we employ SFA to estimate cost efficiency as a measure of performance of investment banks in the G7 and Switzerland. The next and main contribution of this paper is the application of the dynamic panel threshold model by Kremer et al. (2013) in a second stage analysis. The advantage of this methodology is in allowing the data itself to reveal when the financial crisis occurs. This is achieved through testing for threshold effects of major bank determinants with respect to cost performance. In particular, we investigate the existence of thresholds in three bankspecific variables: a) we use Z-Score to measure default risk, as investment bank activities are related to high risk b) liquidity as a key factor that affects the performance of financial institutions. We account for the distinction between investment banks that are part of larger entities and stand-alone banks, as the former are able to draw liquidity from their group; c) we employ investment banking fees, which is the main income source of investment banks. Lastly, we extend the literature concerning investment bank performance determinants by including in fixed effects and dynamic panel models crisis related variables that capture the asset bubble burst and policy responses such as the quantitative easing. ${ }^{4}$

${ }^{4}$ The 2007 turmoil led to the implementation of unconventional monetary policies, such as quantitative easing (Q/E), by the central banks of the G7 and Switzerland (Klyuev, 2009; Fratzscher et al., 2013). 
Our threshold results show that there is a strong positive effect of Z-Score on efficiency, particularly for banks in the low default risk regime. We also find liquidity to have a negative impact on cost performance for investment banks below a threshold value. This effect is mainly driven by banks that are not part of a larger banking entity. Moreover, a higher fee-income ratio has a stronger positive impact on efficiency for investment banks that earn lower fees than for banks with higher levels of non-interest income. Interestingly, we find significant changes in the number of banks that belong to each threshold regime before and during the financial crisis.

The rest of the paper is structured as follows. Section 2 develops our hypotheses. Section 3 describes the SFA and the dynamic panel threshold methodology. Section 4 discusses the investment banking industry in the G7 and Switzerland and presents our data and variables. Section 5 discusses our results and Section 6 concludes.

\section{Hypotheses Development}

The operations of investment banks go far beyond the lending activities of traditional banks as they act as direct intermediaries between investors and capital acquirers in the capital markets. Furthermore, they are active participants in the capital markets by trading securities. An important function of investment banks that differentiates them from traditional banks is their advisory role concerning the wealth of acquirers and bidders. Investment banks assess the assets of target companies and advise acquirers to take the most value enhancing decisions with the aim of creating substantial synergies (Bao and Edmans, 2011). However, the type, the complex nature and the magnitude of investment banking operations carries significant risks that can be transferred to their shareholders and customers. To illustrate this, Fernando et al. (2012) demonstrate that companies with Lehman Brothers as their lead equity underwriter suffered economically, experiencing significant reductions in their returns. Hence, it becomes vital to test the following hypotheses regarding the impact of default risk, liquidity and investment banking fees on the performance of these institutions.

Investment banks are exposed to high risk due to the complexity of their operations. Demirguc-Kunt and Huizinga (2010) argue that higher fee-income for investment banks are linked to a higher volatility of earnings and higher risk as a consequence. However, Chiorazzo et al. (2008) find that for German saving banks an increase in their fee-income generated from investment banking activity has a positive impact on the efficiency of saving banks. The reason being that these banks benefit from the 
diversification of their activities as they are involved in both interest and non-interest income operations (De-Young and Rice, 2004). Similarly, Merciera et al. (2007) show that small European banks and US financial holding companies present low revenue volatility due to their focus on deposit-taking activities, while the shift from interest to non-interest income would result in a trade-off between risk and return. Based on previous studies (see Merciera et al., 2007; Chiorazzo et al., 2008; Demirguc-Kunt and Huizinga, 2010) investment banks might carry more risk due to their engagement in non-interest income activities than savings and commercial banks. To this end, it is vital to examine the impact of risk on investment bank performance.

The 'bad luck hypothesis' states that a negative relationship exists between risk and performance (see Berger and De-Young, 1997). If an unexpected event leads to higher risk, banks react by spending more resources to manage this risk. As a consequence, this procedure can lead to an increase in bank costs. Consistent with the 'bad luck hypothesis', Wheelock and Wilson (2000) find that inefficient banks are closer to failure. Similarly, investment banks' performance (measured by cost efficiency) is negatively associated with insolvency risk as defined by the Z-Score (Radic et al., 2012). Consequently, it would seem that investment banks with lower default risk are more efficient than banks with higher default risk. Interestingly, banks with high default risk aiming to decrease their probability of default, are forced to divert more resources to short-term screening and monitoring operations and could in fact become less efficient this way. Thus, our first hypothesis is as follows:

$H_{1}$ : Lower default risk asserts a positive impact on performance of investment banks. Furthermore, investment banks, due to the absence of a deposit base, face higher liquidity risk in comparison with commercial banks (Gatev and Strahan, 2006; Gatev et al., 2009). Brunnermeir (2009) demonstrates that investment banks' reliance on short-term debt, such as repurchase agreements, could escalate their liquidity risk. Similarly, other studies (Adrian and Shin, 2008, 2009; Krishnamurthy, 2009; Brunnermeir and Pederson, 2009) argue that investment banks face more difficulties to raise capital during periods of financial distress than deposit-taking banks. In light of this, an investigation of the relationship between liquidity and investment bank performance would be warranted.

Moreover, banks with higher levels of liquidity might undertake less risk in a case of an unexpected financial shock than banks with lower levels of liquidity. There are 
numerous studies that examine the impact of liquidity on bank performance (Altunbas et al., 2000; Brissimis et al., 2008; Altunbas and Marques, 2008). Many studies find a direct positive relationship between a bank's liquidity ratio and its performance (Bourke, 1989; Demirguc-Kunt and Huizinga, 1999; Athanasoglou et al., 2008). Nonetheless, there are counterarguments: excess liquidity is accompanied by high storage costs (Kwan, 2003; Staikouras et al., 2008) and lower returns (Pasiouras and Kosmidou, 2007), suggesting that while liquid assets could decrease liquidity risk they could carry high costs that negatively affect bank performance.

We assume that banks with higher liquidity perform better than banks with lower levels of liquid assets. By this logic ('bad luck hypothesis' by Berger and De-Young, 1997), banks with lower liquidity would underperform banks with more liquid assets while trying to raise their liquidity levels. Hence, our second hypothesis is as follows:

$\mathrm{H}_{2}$ : Higher liquidity asserts a positive impact on performance of investment banks.

Rau (2000) casts the reputation effect of investment banks as the 'superior deal hypothesis'. He suggests that the amount of investment banking fees is an accurate reflection of an investment bank's quality. Investors are willing to pay higher fees to more reputable investment banks than to less reputable ones (Beatty and Welch, 1996; Hunter and Jagtiani, 2003; Fang, 2005; Ismail, 2008).

On the other hand, Demirguc-Kunt and Huizinga (2010) find that for banks earning high levels of non-interest income, to raise fee-income (such as investment banking fees) would induce higher risk. Thus, the positive effect of raising fee-income on bank performance via risk diversification would be stronger for banks with low levels of noninterest income. Moreover, De-Young and Roland (2001) argue that the substitution of traditional operations with fee-income activities is related to an instability of earnings, while Acharya et al. (2006) show that banks with higher inclusion of non-interest income activities in their portfolio perform less efficiently than banks with lower involvement in fee-income operations. In the same manner, Stiroh (2004) and Lepetit et al. (2008) find a positive association between fee-based revenue and bank risk. Yet for saving banks an increase in fee-income could have a positive impact on performance (Chiorazzo et al., 2008), as these banks engage in both interest and non-interest income operations and thereby diversify their risk (De-Young and Rice, 2004). On the contrary, investment banks since they solely focus on investment banking activities could benefit 
less from risk diversification compared to saving banks. It is clearly of interest to study the impact of fee-income on investment bank performance.

It follows that we should expect the scope to increase fee-income, without increasing risk, is higher for investment banks that earn relatively low levels of fee-income (i.e. less reputable banks). Therefore, our third hypothesis is as follows:

$H_{3}$ : Less reputable investment banks, here considered as banks that earn relatively low levels of investment banking fees, could benefit more from an increase in fees than would more reputable banks that earn higher levels of fee-income.

\section{Methodology}

\subsection{Measuring Cost Efficiency}

In this study we measure bank performance in terms of cost efficiency by employing Stochastic Frontier Analysis (SFA). The advantage of this parametric methodology is that both random error and inefficiency are combined in a composite error term (Berger and Humphrey, 1997). More specifically, we use the following specification for the cost frontier:

$$
T C_{i t}=f\left(P_{i t}, Y_{i t}, N_{i t}, Z_{i t}\right)+v_{i t}+u_{i t}
$$

where $T C_{i t}$ is the total cost for bank $i$ in year $t$. Total cost is defined as the sum of personnel, interest and non-interest expenses. $P_{i t}$ is a vector of input prices, $Y_{i t}$ is a vector of outputs, $N_{i t}$ is a vector of fixed netputs and $Z_{i t}$ is a vector of control variables. We use country dummy variables to control for home country characteristics ${ }^{5}$ and a dummy variable for listed banks. The term $v_{i, t}$ stands for the error term, while $u_{i, t}$ denotes bank's inefficiency.

The translog cost function, opted in the paper, takes the form:

$$
\begin{aligned}
& \ln C_{i, t}=\alpha_{0}+\sum_{i} \alpha_{i} \ln P_{i, t}+\sum_{i} \beta_{i} \ln Y_{i, t}+1 / 2 \sum_{i} \sum_{j} \alpha_{i j} \ln P_{i, t} \ln P_{j, t}+1 / 2 \sum_{i} \sum_{j} \beta_{i j} \ln Y_{i, t} \ln Y_{j, t}++\sum_{i} \sum_{j} \delta_{i j} \ln P_{i, t} \ln Y_{j, t}+ \\
& \sum_{i} \zeta_{i} \ln N_{i, t}+1 / 2 \sum_{i} \sum_{j} \zeta_{i j} \ln N_{i, t} \ln N_{j, t}+1 / 2 \sum_{i} \sum_{j} \theta_{i j} \ln P_{i, t} \ln N_{j, t}++\sum_{i} \sum_{j} \kappa_{i j} \ln Y_{i, t} \ln N_{j, t}+\mu_{1} t+1 / 2 \mu_{2} t^{2}+ \\
& \sum_{i} v_{i} t \ln P_{i, t}+\sum_{i} \xi_{i} \operatorname{tln} Y_{i, t}+\sum_{i} \rho_{i} t \ln N_{i, t}++\sum_{\iota} \varphi_{i} Z_{i, t}+u_{i, t} \pm v_{i, t}
\end{aligned}
$$

\footnotetext{
${ }^{5}$ Structural and macroeconomic conditions might create variances in efficiency from country-to-country and time-to-time. To control for these differences we employ both time effects and country effects in the estimation of the efficiency as in Bonin et al. (2005).
} 
Standard linear homogeneity and symmetry restrictions are applied. The equation (2) is estimated via a maximum likelihood procedure parameterized in terms of the variance parameters:

$$
\begin{aligned}
& \sigma_{\varepsilon}^{2}=\sigma_{u}^{2}+\sigma_{v}^{2} \\
& \quad \text { and } \beta=\sigma_{u}^{2} / \sigma_{\varepsilon}^{2}
\end{aligned}
$$

We estimate bank-specific efficiency scores using the distribution of the efficiency term conditional to the estimate of the composite error term, as in Jondrow et al. (1982).

\subsection{Dynamic Panel Threshold Model}

We choose to implement this methodology as it enables us to identify regime changes of important determinants of investment bank performance as measured by cost efficiency. Specifically, we employ the model of Kremer et al. (2013), which is an extension of Hansen (1999) model. It is based on the cross sectional threshold model of Caner and Hansen (2004), where GMM estimators are used to allow for endogeneity. However, Kremer et al. (2013) opt for a dynamic unbalanced threshold model, which could identify possible coefficient changes on the independent variables of our interest.

The threshold model takes the following form:

$e f f_{i t}=\mu_{i}+\lambda_{1} m_{i t} I\left(q_{i t} \leq \gamma\right)+\delta_{1} I\left(q_{i t} \leq \gamma\right)+\lambda_{2} m_{i t} I\left(q_{i t}>\gamma\right)+\varepsilon_{i t}$

where $e f f_{i t}$ is the dependent variable (efficiency scores derived from SFA), $\mu_{i}$ is the bank-specific fixed effect, while $\lambda_{1}$ and $\lambda_{2}$ are the two reverse regression slopes assuming that there are two regimes. The threshold variable is $q_{i t}$, whereas $\gamma$ is the threshold value which categorizes the observations above (high regime) and below the threshold value (low regime). $\varepsilon_{i t}$ is the error term. I is the indicator function signifying the regime indicated by the threshold variable $\mathrm{q}_{i t}$ and the threshold value $\gamma$. This model by Kremer et al. (2013) treats $m_{i t}$ as a vector of explanatory variables, which includes one regressor that is correlated with the error term and other regressors, which are not. Moreover, Kremer et al. (2013) extends Hansen's (1999) specification by the regime dependent intercept, $\delta_{1}$. According to Bick (2007), ignoring the regime intercepts would result in inconsistent estimates for both the threshold value and the coefficient magnitude of the regimes.

In order to circumvent serial correlation in the transformed error terms, Kremer et al. (2013) opt for the GMM estimation method (Arellano and Bover, 1995). To obtain its 
predicted values, Kremer et al. (2013), like Caner and Hansen (2004), estimate a reduced type regression for the endogenous variable as a function of instruments. In the first step, the predicted values replace the endogenous variable in the equation (4). In step two, equation (4) is estimated via ordinary least squares for a fixed threshold value where the threshold variable is replaced by its predicted values obtained in the first step. The optimal threshold value is derived from the minimization of the concentrated sum of squared errors (Chan, 1993; Hansen, 1997). The 95\% confidence interval of the threshold value is given by $\Gamma=\{\gamma: L R(\gamma) \leq C(a)\}$, where $C(a)$ represents the asymptotic distribution of the Likelihood Ratio (LR) statistic at the 95\% level (Hansen, 1999; Caner and Hansen, 2004). The above likelihood ratio has been adjusted to control for the number of time periods used for each cross section (Hansen, 1999). After the threshold value has been estimated, the slope coefficients $\lambda_{1}$ and $\lambda_{2}$ could be determined by the GMM estimator (Caner and Hansen, 2004).

\section{Investment banking in the G7 and Switzerland and Data/Variables 4.1 Investment banking in the $G 7$ and Switzerland}

Investment banking industry in the G7 and Switzerland demonstrated strong growth for the most part of the last decade and reached its peak in 2006. Due to the financial crisis investment banking activities were substantially subdued in 2008. This slowdown has been reversed during recent years and the investment banking continues to form an important part of the financial markets in industrialised economies. ${ }^{6}$

In North America, the US investment banks generated 58\% of the global investment banking revenues in 2012, while $30 \%$ of US banking industry profits were from investment banking operations in the same year (Thomson Reuters, 2013). As a part of North America, Canadian banks facilitated the access of domestic issuers into foreign capital, resulting in a rapid growth of cross-border M\&A operations.

In Europe, the UK, as one of the leading financial markets, constitutes an important hub for international investment banking activities carried out by numerous foreign banks from Italy, Germany, the US, Switzerland and Japan (Burgess, 2011). Switzerland is another important financial centre. A large part (13\%) of the income of

\footnotetext{
${ }^{6}$ Among the top fee-generating investment banks worldwide are: JPMorgan, Goldman Sachs and Bank of America Merrill Lynch in the US; Barclays in the UK; Deutsche Bank in Germany; BNP Paribas in France; Mediobanca and Banca IMI in Italy; Credit Suisse and UBS in Switzerland; RBC Capital Markets in Canada; and Nomura in Japan (Thomson, 2013).
} 
Swiss banks was generated from M\&A activity in 2010 (Swiss Bankers Association and Boston Consulting Group, 2011). In the German banking system universal banks perform both commercial and investment banking operations. International investment banking in Germany, in particular the M\&A, has developed substantially following the Tax Reduction Act in 2000 (Schroder et al., 2012). French investment banks primarily engage in market-based activities, such as trading of securities, and have a relatively lower number of investors than UK and German banks, which also involve off-balance sheet activities (Vinals and Moghadam, 2012). Banks in Italy play a more predominant role in financing firms than those in Germany, France and the UK (Caselli et al., 2013).

In Japan, which is the only Asian country in the G7, the operational framework of investment banks has been strengthened since 2001. During this period, banks in Japan adopted most of the operations that typical investment banks should cover. Moreover, following the legislation of 2007, foreigners were able to acquire Japanese firms by using their own stock (Stowell, 2012) enabling a higher level of M\&A activity.

In all countries considered, the investment banking has largely grew for the greater part of the last decade, as evident in the market capitalization data (see Figure 1). Market capitalization represents the equity aspect of financing and constitutes a major function of investment banks in the primary market. Figure 1 shows the domestic market capitalization in the G7 and Switzerland for the period 2000-2010 (as \% of GDP). We observe that market capitalization peaks in 2000 and 2007, which would suggest thriving periods for stock prices before the technology bubble burst in 2001 and the financial crisis in the end of 2007.

\section{[INSERT FIGURE 1 ABOUT HERE]}

Figure 2 shows M\&A activity of firms operating in the G7 and Switzerland over 20002010. M\&A activity constitutes the main source of fee-income for investment banks (Kolasinski and Kothari, 2008). It is of note that during periods of financial stability (2004-2007) M\&A transactions increased, while they declined during times of economic recession (2001-2003 and 2008-2009). The G7 and Switzerland reached a total transaction value of 3.48 (US\$tr) for M\&A in 2000, which was to decrease sharply to 1.14 (US\$tr) in 2003. From this low level of M\&A activity, transaction value grew considerably to a total 3.58 (US\$tr) in 2007 while decreased significantly to 1.53(US\$tr) in 2010 . 


\section{[INSERT FIGURE 2 ABOUT HERE]}

\subsection{Data and Variables}

We use financial data from the Fitch IBCA's Bankscope database over the period 19972010. Our sample includes 97 investment banks and a total of 707 observations for the following countries: the US, the UK, Italy, Germany, Canada, Japan, France and Switzerland. Out of these 97 investment banks, 66 belong to a banking group while the rest (33) are stand-alone investment banks. ${ }^{7}$

We follow Sealey and Lindley (1977) in employing the 'intermediation' approach to identify bank inputs and outputs. This approach assumes that the core function of banks is to use labour and capital in order to collect funds and transform them into loans and other earning assets. As inputs we use labour and physical capital. The price of labour is measured as the ratio of personnel expenses to total assets while the price of physical capital as the ratio of operating expenses to fixed assets. As output we employ other earning assets including loans, deposits from banks and credit institutions, government securities, and derivatives among others. Given that we are dealing with investment banks we opt for investment banking fees as an additional output (Radic et al., 2012). Investment banking fees comprise a wide range of operations including trading gains, net commission and other fees. Fixed netputs include the total level of equity and of fixed assets. By including equity we correct for biases in our efficiency scores, as banks with high levels of equity are more likely to adopt risk adverse strategies to protect shareholders' wealth than banks with lower levels of equity (Berger and Mester, 1997). To be consistent with the literature we also include the levels of fixed assets for each bank as a proxy for physical capital (Berger and Mester, 1997). We also include the following control variables: country dummies ${ }^{8}$ to count for time-invariant home country characteristics and a dummy for listed banks. Table 1 presents descriptive statistics of cost function variables. The main impression emerging from this table is similar with that which has been previously observed (Radic et al., 2012).

\section{[INSERT TABLE 1 ABOUT HERE]}

To test for the 'bad luck hypothesis' (H1) that a decrease default risk asserts a positive impact on investment banking performance, we employ Z-Score as a measure of risk.

\footnotetext{
${ }^{7} \mathrm{We}$ thank the anonymous referee for pointing out this distinction. Subsidiary banks as a part of a larger banking entity could benefit from liquidity injections from the parent bank (Mayer and Carlyn, 2008).

${ }^{8} \mathrm{As}$ it is expected one dummy variable (Japan) is dropped from the sample to avoid multicollinearity issues.
} 
We compute Z-Score as in Boyd and Graham (1986) by using the following formula: Z-Score $=(1+\mathrm{ROE}) /$ Standard Deviation of ROE. The Z-Score has been used widely in recent banking studies (Lepetit et al., 2008; Barry et al., 2011; Radic et al., 2012). Banks with lower Z-Score have higher risk to default than banks with higher Z-Score. We also test the 'bad luck hypothesis' (H2) whereby an increase in liquidity asserts a positive impact on investment banking performance. Liquidity is defined for each bank as the ratio of liquid assets to total assets. This specification has been employed extensively in the literature (Altunbas et al., 2000; Kwan, 2003; Altunbas and Marques, 2008). Liquid assets include trading assets, loans and advances with less than three months' maturity. Lower values of this ratio suggest that banks face more liquidity risk than banks with higher liquidity ratio. In addition, we use an income-associated ratio to test for the third hypothesis $(\mathrm{H} 3)$ whereby less reputable investment banks, defined as banks that earn relatively low levels of investment banking fees, would benefit more by an increase in fees than more reputable banks (institutions that earn high levels of feeincome). This ratio is defined as the sum of net commission, fees and net trading income over total assets. The conventional ratio of net income to total assets in the literature (Morgan and Stiroh, 2001; Bonin et al., 2005; Beccalli, 2007; Micco et al., 2007; Lin and Zhang, 2009) is replaced by the ratio of investment banking fees to total assets. This transformation reflects the core revenue of investment banks that stems from nontraditional banking activities.

In terms of bank-specific characteristics, we opt for a number of additional variables such as the ratio of equity to total assets as a proxy of capital (Athanasoglou et al., 2008; Lepetit et al., 2008). We also use the ratio of securities to total assets as in Radic et al. (2012) to account for the varieties of investment banking operations concerning equity issuance and underwriting activities. Finally, we examine the impact of income diversification on bank performance as has been used in recent studies (Laeven and Levine, 2007; Fiordelisi and Molyneux, 2010). ${ }^{9}$

In terms of country macroeconomic variables, we use GDP per capita as a wealth measure (Dietsch and Lozano-Vivas, 2000; Maudos and Guevara, 2007; Maudos and Solis, 2009; Fiordelisi et al., 2011). Empirical evidence and theory point in different directions concerning the impact of GDP per capita on bank performance. An increase

${ }^{9}$ Income diversification $=(1-\mid$ Net Interest Income-Other Operating Income $\mid) /$ Total Operating Income. 
of GDP per capita could result in the decline of banking costs as banks in more prosperous countries could benefit from access to new technologies (Lensink et al., 2008). On the other hand, an increase of GDP per capita could increase banking costs due to higher operating expenses to supply a given level of services (Dietsch and Lozano-Vivas, 2000).

To account for financial development, we include domestic credit to the private sector (DCPS) as a percentage of GDP. This is a proxy of banking activity, used in numerous studies as an indicator of financial development (Levine, 1997; Beck et al., 2004; Shandre and James, 2004; Abu-Bader and Abu-Qarn, 2008). Financial development could have a positive impact on cost efficiency (Pasiouras, 2008; Lozano-Vivas and Pasiouras, 2010). However, Demirguc-Kunt and Maksimovic (2002) argue that banks with a primary role in financing firms might undertake high loan default risk during a period of financial distress.

Higher FDI inflows may denote a higher presence of foreign investment banks in a country. If foreign banks manage to overcome the cross-border differences, they might increase the efficiency of the investment banking industry of a country (Berger et al., 2000). Higher FDI outflows suggest a high internationalisation of domestic investment banks. Banks that are able to expand globally have superior practices and structures. Consequently, higher FDI outflows can signify that the most efficient banks go abroad to transfer their model. Thus, we expect FDI outflows to have a negative impact on efficiency (Beccalli, 2004).

Moreover, we include the real effective exchange rate to control for exchange rate risk that investment banks could face due to foreign currency activities. The impact of the exchange rate on bank performance is subject to the net asset position of a bank in foreign currencies. A depreciation (appreciation) of the national currency with respect to a specific foreign currency, while the net asset position of a bank denominated in this foreign currency is positive (i.e. assets larger than liabilities), could lead to increased (decreased) gains for this bank (Grammatikos et al., 1986).

We also use the stock and house price index of the countries considered (S\&P500, FTSE100, DAX, CAC, FTSEMIB, SMI, SPTSX and NIKKEI), with the aim of capturing the asset price bubble, as in Bordo and Jeanne (2002). A recent study by Adrian and Song Shin (2010) shows that when the asset and stock prices rise, 
investment banks' leverage increases as well. Moreover, in order to control for asset bubble bursts, we follow Gerdesmeier et al. (2010) and adopt a composite asset price indicator to construct a dummy, which takes the value of 1 in case of an asset price burst, and 0 otherwise. ${ }^{10}$

In addition, we proxy $\mathrm{Q} / \mathrm{E}$ by using the reserves held by central banks for the countries considered, following the definition of Kobayashi et al. (2002) who suggests that $Q / E$ stands for the increase in central bank reserves. A number of recent studies look at the impact of Q/E policy on the economies of Japan and UK (Voutsinas and Werner, 2011b; Lyonnet and Werner, 2012) using central bank reserves, among other tools of Q/E, and highlight the positive impact of this non-conventional monetary policy. ${ }^{11}$ Hence, we expect the impact of central bank reserves on bank performance to be positive, as in Kobayashi et al. (2006).

Finally, to account for market risk we use the Volatility Implied Index (VIX). This financial indicator suggests that higher levels of VIX reflect higher degrees of financial turmoil in the US (Whaley, 2000). It follows that we should expect the VIX impact on investment bank performance to be negative. Over the study period (1997-2010), we observe that volatility increases significantly in two instances: over 2001-2003 and 2008-2009 (see Figure 3). Over 2004-2007 the relative market risk is lower, suggesting a period of financial stability.

\section{[INSERT FIGURE 3 ABOUT HERE]}

\footnotetext{
${ }^{10}$ If the composite indicator falls below a critical value the dummy takes the value of 1 , and 0 otherwise. For the values of the composite indicator that are below the threshold value a burst exists. The critical value is determined as the mean of the composite indicator minus the standard deviation of the composite indicator times the factor $\mu$. In our study we use $\mu=0.5$, similarly to the study of Gerdesmeir et al. (2010) where $\mu=0.75$. The composite indicator is estimated by the following equation: $C I=$ $\varphi_{1}$ stock price index $+\varphi_{2}$ house price index. $\varphi_{1}$ equals to 1 , while $\varphi_{2}$ is the ratio of the standard deviation of the stock price index over the standard deviation of the house price index. Alternatively, Voutsinas and Werner (2011a) indicate the boom and the burst phase in their study based on the trend of lending growth rate in Japan over the 1980-1999 periods. The dummy variable equals 1 over the boom period (1980-1989), and 0 during the burst period (1990-1999).

${ }^{11}$ In the study of Voutsinas and Werner (2011b) the case of Japan has been examined, as being the first country to implement the unconventional monetary policy of Q/E. In the early 90s Japan has experienced very low interest rates, triggering the implementation of new monetary policies. Similarly, Lyonnet and Werner (2012) look at the impact of Q/E on the nominal GDP growth for the UK. Only recently (2008), the Bank of England has implemented the relevant monetary policy (Joyce et al., 2011). The studies of Voutsinas and Werner (2011b) and Lyonnet and Werner (2012) investigate the impact of Q/E on the nominal GDP growth of Japan and UK respectively and conclude that credit creation, the original definition of Q/E (Werner, 1995), could form a stable relationship between a lending aggregate for GDP transactions and nominal GDP growth.
} 
Table 2 shows further descriptive statistics of the bank-specific and country-level variables used in the fixed effect and dynamic panel regressions.

\section{[INSERT TABLE 2 ABOUT HERE]}

Note that UK and US investment banks have lower default risk (the highest two ZScores of 2.346 and 2.262). French and Japanese investment banks have the highest default risk with Z-Scores of 1.282 and 0.656 . US investment banks have the highest level of investment banking fees over total assets. In terms of the liquidity ratio, Switzerland, Canada and Japan have the highest ratios, while Germany and Italy have the lowest.

\section{Results and Discussion}

\subsection{Cost Efficiency Estimations}

Table 3 shows the mean cost efficiency scores. Our mean efficiency scores rank Japan, Switzerland and Germany in the first three places. Our findings are broadly in line with Radic et al. (2012) who find that Japan and Switzerland rank in the second and third place. However, unlike in the present study, they find that US investment banks are the most cost efficient among the considered countries (G7 and Switzerland). Their study focuses on the pre-crisis period (2001-2007) and so misses the post financial turmoil period where the US investment banking industry confronted severe losses.

\section{[INSERT TABLE 3 ABOUT HERE]}

In Figure 4, we report changes in the mean efficiency score over time. We observe a downward trend from 2004 to 2008. In 2003, the average efficiency score is $75.93 \%$. It decreases to $72.26 \%$ in $2005,66.60 \%$ in 2007 and $65.68 \%$ in 2008. It would appear that performance was affected adversely by the financial crisis of the 2007-2009 period.

\section{[INSERT FIGURE 4 ABOUT HERE]}

\subsection{Panel Estimations}

\subsubsection{The Impact of the Z-core, Liquidity and Investment banking fees}

Tables 4 and 5 present the results for the fixed effect and dynamic panel regressions, where bank performance is a function of bank-specific and country-level variables. In the dynamic panel analysis we employ the two-step system GMM estimator of Arellano and Bover (1995) and Blundell and Bond (1998) with Windmeijer (2005) corrected (robust) standard errors. The two main characteristics of this estimator is that it follows the moments conditions on the level equations and uses the orthogonality conditions 
introduced by the Arellano and Bond (1991) model. This method serves as a control for possible biases brought by country specific effects and endogeneity issues. ${ }^{12}$

\section{[INSERT TABLE 4 and 5 ABOUT HERE]}

Consistent with Radic et al. (2012) and Berger and De-Young (1997), the fixed effect results reveal a positive relationship between the Z-Score and bank performance at the $5 \%$ level of significance (Model 1 in Table 4). This finding remains robust when we control for the rest variables of our main interest (Model 4 in Table 4), which are the liquidity ratio and investment banking fees. Similarly, the dynamic panel analysis shows that the Z-Score exerts a positive impact at the $5 \%$ level of significance on cost efficiency (Model 1 and 2 in Table 5). These results lend support to our first hypothesis (H1), the 'bad luck hypothesis'. Moreover, the fixed-effect regressions indicate a positive effect of investment banking fees over total assets ratio on cost efficiency at the $10 \%$ level of significance (Model 4 in Table 4). Dynamic panel results provide additional evidence of the positive relationship between fee-based income and cost performance (Model 2 and 4 in Table 5). This implies that banks with higher amounts of net income are more efficient (Bonin et al., 2005; Beccalli, 2007; Micco et al., 2007; Lin and Yzhang, 2009). We also find a positive association between the liquidity ratio and cost performance at the 5\% level of significance (Model 4 in Table 4) in the fixed effect model. While the dynamic panel analysis indicates that the liquidity ratio has a positive impact on bank performance, the result is not robust (Model 3 and 4 in Table $5)$. It appears that the results would confirm our second hypothesis $\left(\mathrm{H}_{2}\right)$ and previous empirical work suggesting a positive relationship between liquidity and bank performance (Bourke, 1989; Demirguc-Kunt and Huizinga, 1999; Athanasoglou et al., 2008).

\footnotetext{
${ }^{12}$ Here, we employ as endogenous explanatory variables the lagged efficiency score, Z-Score, liquidity and fee-income ratios. According to Athanasoglou et al. (2008) in order to test the endogeneity of the variables we run the model twice. The first time we treated the three variables, Z-Score, liquidity and fee-income ratios, as investment banks' endogenous variables, while all the other determinants as strictly exogenous. The second model treated all the variables as exogenous. The results support the hypothesis that bank specific-variables are better modelled as endogenous and country-level as exogenous (in accordance with Delis, 2012), because the Sargan test has 1.00 p-value. This suggests that the instruments are acceptable. On the other hand, in the case where all variables are treated as exogenous the $p$-value of the Sargan test is 0.003 . For the GMM estimation we use Roodman (2006) 'xtabond 2' specification in Stata.
} 
The findings above show that risk, estimated as the Z-Score, liquidity and fee-income ratios are significant determinants of investment banking performance over the 19972010 period. We go a step further in the next section (5.3) and employ the flexible approach of the dynamic panel threshold model (Kremer et al., 2013) to identify thresholds in these three variables with respect to cost efficiency and different underlying regimes over the crisis period. This is essential due to both the inherent volatility of non-interest income (De-Young and Roland, 2001) which can rise in crisis periods and also because of the importance of default risk and the low availability of liquidity during recessions.

\subsubsection{Impact of the Control Variables}

Concerning other bank-specific variables, we find that the ratio of equity to total assets has a significantly positive impact on cost efficiency at the $5 \%$ level in the fixed effect model (Model 1 in Table 4) and at the 10\% level of significance in the dynamic specifications (Models 2, 3 and 4 in Table 4). These results indicate that more capitalized banks are more cost efficient as in Athanasoglou et al. (2008) and Lepetit et al. (2008). The securities to total assets ratio has a positive effect on performance at the $1 \%$ level of significance both in the fixed and dynamic panel regressions (all Models in Table 4 and 5). This finding suggests that off-balance sheet activities may induce a higher risk of bank losses (Radic et al., 2012). Finally, results from fixed and dynamic panel regressions reveal that the income diversification variable asserts a negative impact on cost efficiency at the $1 \%$ level of significance (all Models in Table 4 and 5).

Next we turn to the impact of the country-level control variables on cost efficiency. An important finding relates to the policy measure of $\mathrm{Q} / \mathrm{E}$ that has been implemented by many countries in order to weather the financial crisis. In particular, we find central bank reserves, a proxy of $\mathrm{Q} / \mathrm{E}$, to have a positive and significant relationship with cost efficiency in both fixed effect and dynamic panel regressions (all Models in Table 4 and 5). This result would suggest that in countries where the $\mathrm{Q} / \mathrm{E}$ has been broadly implemented, investment banks perform better than in countries where the $\mathrm{Q} / \mathrm{E}$ has been applied at a lower level. This finding is consistent with recent studies that provide evidence of a positive impact of $\mathrm{Q} / \mathrm{E}$ on economic outcomes (Voutsinas and Werner, 2011b; Lyonnet and Werner, 2012) and justifies, from an investment banking perspective, the use of such unconventional monetary policies. The countries of our sample that have implemented Q/E at a large scale are Japan, the UK and the US. The 
Bank of Japan is the first to follow this policy (Lyonnet and Werner, 2012). Furthermore, in response to the intensification of the financial crisis, the Bank of England implemented Q/E in the form of asset purchases backed by the central bank (Joyce et al., 2011). Similarly, the Federal Reserve launched a new set of nonconventional monetary 'tools', termed as 'crediting easing', in order to rise the liquidity of the markets after the collapse of Lehman Brothers. The rest of the economies in our sample, the ones belonging to the Eurozone area, also engaged in $\mathrm{Q} / \mathrm{E}$ but at a lower extent in comparison with the large asset purchases in the US and the UK (Martin and Milas, 2012; Reichlin, 2013).

Our fixed and dynamic panel analysis reveals that both the house price and the stock price index have a negative and significant impact on cost efficiency. ${ }^{13}$ As expected, a bubble burst has a negative impact on investment bank performance due to decreased investment activity (Allen and Carletti, 2010). ${ }^{14}$ We also find a strong negative effect of the VIX indicator on bank performance at the $1 \%$ level of significance (all Models in Table 4) in line with previous studies (Bourke 1989; Miller and Noulas, 1997). Moreover, GDP per capita has a negative impact on cost efficiency, suggesting the higher operating and financial costs for supplying a particular level of service (Dietsch and Lozano-Vivas, 2000). FDI inflows have a negative impact on cost performance, in line with Berger et al. (2000). Similarly, FDI outflows have negative impact on bank performance, suggesting that most efficient banks go abroad to export their model (Beccalli, 2004). As for the financial development indicator, we find that the DCPS/GDP ratio has a statistically significant negative effect on cost efficiency, consistent with Demirgunt-Kunt and Maksimovic (2002).

\footnotetext{
${ }^{13}$ These results show that during boom periods, where a rise of asset and stock prices takes place, there exists a deterioration of investment bank performance. A recent study by Adrian and Song Shin (2010) shows that when the asset and stock prices rise, investment banks' leverage increases as well in a procyclical manner. At low levels of leverage, any increase in leverage might moderate the conflicts between shareholders and managers regarding the choice of investment and the underlying risk (Myers, 1977). This is so because managers would need cash to service the debt rather than take excessively risky investments (Jensen and Meckling, 1976). However, when leverage becomes relatively high, any increase in leverage might raise conflicts between debt holders and shareholders, mainly due to the higher risk of default or liquidation (Jensen and Meckling, 1976). These conflicts would escalate agency costs between debt holders and shareholders and this would result in higher interest expenditures to pay debt holders for their estimated losses.

${ }^{14}$ The bubble-burst indicator shows that there are two major bursts that concern the majority of the sample, these occur in the 2001-2003 and 2008-2010 periods. For all countries in the sample we identify the 2001-2003 burst. The latter result corresponds to the technology bubble burst in 2001, while the second burst (2008-2010) coincides with the recent financial flood of 2007 (Lin, 2009).
} 


\subsection{Threshold Estimations}

\subsubsection{Z-Score Threshold}

Our empirical estimations for threshold effects are based on an unbalanced dataset of 707 observations including 97 banks for the period 1997-2010. Table 6 presents the dynamic panel threshold model with the Z-Score as threshold variable. ${ }^{15}$

\section{[INSERT TABLE 6 ABOUT HERE]}

We find that the threshold value for the Z-Score variable is 1.516 (see Table 6). This value splits the sample into two regimes: the first regime consists of banks with a relatively high risk of default; the second consists of banks with lower risk. The coefficient $\lambda_{2}=0.044$ for banks within the high regime is positive and significant at the $5 \%$ level. This implies that a $1 \%$ decrease in Z-Score would benefit efficiency by $4.4 \%$. This result is consistent with our first hypothesis $\left(\mathrm{H}_{1}\right)$. A decrease in default risk for banks with low Z-Score, below the threshold value, is also significant at the 5\% level and positively related to cost efficiency $\left(\lambda_{1}=0.012\right)$, although here at a lower magnitude than the one of the high regime.

In Table 7, the percentage of investment banks classified as low-regime is consistently above the percentage of banks classified as high-regime with respect to the Z-Score. Note between 2000 and 2003 there is a clear negative trend in the number of investment banks with low exposure to risk (46 investment banks in 2000 decreases to 18 in 2003). The composite indicator of asset prices reveals the burst during 2001-2003, while the VIX indicator shows higher levels of risk during the same period (Figure 3). Between 2004 and 2007, we observe a decreasing trend in the percentage of investment banks that have high risk exposure, when according to the VIX indicator there should be lower market volatility. Finally, the percentage of investment banks with low risk exposure (the high regime) has decreased significantly since 2008 due to the crisis. This result is supported by the identification of the 2008-2010 burst, when again the associated risk (VIX) increases considerably (Figure 3).

\section{[INSERT TABLE 7 ABOUT HERE]}

\footnotetext{
${ }^{15}$ We perform a general to the specific sensitivity analysis. In the first stage, we employ a wide range of instruments while in the second stage we include only one instrument. We find no significant difference in our results. We follow the same procedure for the liquidity and investment banking fees threshold analysis. The results are available on request.
} 
Concerning the other bank specific variables, we find that the equity and securities to total assets ratios have a positive and significant relationship with cost efficiency. On the other hand, income diversification has a negative effect on performance. In terms of country-level determinants, we find that FDI inflows, house price and stock price index, bubble bursts and VIX indicator have a negative and significant impact on efficiency. Moreover, central bank reserves have a positive effect on efficiency. Overall, our results are similar to the fixed effect and the dynamic panel regressions.

\subsubsection{Liquidity Threshold}

Table 8 presents the threshold effects due to liquidity measured as the ratio of liquid assets to total assets.

\section{[INSERT TABLE 8 ABOUT HERE]}

Again we find evidence of two regimes. A liquidity threshold value of around 0.230 splits the sample into (i) banks with low liquidity ratios (higher liquidity risk) and (ii) banks with high liquidity ratios (lower liquidity risk). We find a negative and significant (at the 5\% level) relationship between liquidity and performance for banks within the low regime (high liquidity risk) as $\lambda_{1}=-0.202$. This result is consistent with the findings of Kwan (2003) and Staikouras et al. (2008). On the other hand, the impact of liquidity on bank performance for the banks in the high regime is rather inconclusive as it is not significant, yet it takes a positive sign as in Athanasoglou et al. (2008).

Table 9 shows the classification of banks over time based on the liquidity threshold value (0.23). This classification implies that there are more banks classified in the high liquidity regime as opposed to the low one over the whole period. This also indicates that the majority of investment banks fall within the category of high liquidity and hence carry less liquidity risk in the event of a financial shock. Nonetheless, the number of banks within the low regime increases from $28 \%$ in 2007 to $37 \%$ in 2009.

\section{[INSERT TABLE 9 ABOUT HERE]}

For the remaining bank-specific determinants, we find that investment banking fees, equity and securities to total assets ratios have a highly significant and positive impact on cost performance (see Table 8) while the income diversification variable has a negative impact on efficiency at the $1 \%$ level of significance. For the country-level variables, we find that FDI inflows, stock price index, bubble burst and VIX indicator 
have a strong negative impact on cost performance. Additionally, central bank reserves continue to have a strong positive effect on cost performance at the $1 \%$ level of significance.

\subsubsection{Investment Banking Fees Threshold}

In this section, we use the ratio of investment banking fees to total assets as the threshold variable to test the effect of investment banking fees on cost efficiency performance. We present our findings in Table 10.

\section{[INSERT TABLE 10 ABOUT HERE]}

The threshold value of fee-income is around 0.009 . The variable splits the sample into two regimes. In line with Demirguc- Kunt and Huizinga (2010) we find that for banks with low levels of investment fees (for banks in the low regime) an increase in fees asserts a positive and significant (at the 5\% level) impact on performance as $\lambda_{2}=0.216$. This finding supports our third hypothesis (H3). Nonetheless, banks within the high regime exhibit a decrease in performance when fees increase, but in this case this effect is not statistically significant.

Between 1998-2007 we observe a stable increase in the percentage of investment banks that belong in the low fee regime that peaks in 2008, while in 2009 and 2010 there is a decrease in banks that fall within this regime (see Table 11).

\section{[INSERT TABLE 11 ABOUT HERE]}

Regarding the other cost efficiency correlates, we find equity to total assets to have a strong positive impact on cost performance. As in with our previous findings, income diversification has a strong negative effect on investment banking performance at the $1 \%$ level of significance. The relationship between FDI inflows, stock price index, bubble burst and VIX indicator and efficiency remains negative and significant, in line with our previous results. Lastly, central bank reserves stimulate the cost efficiency of investment banks.

\subsubsection{Does the impact of liquidity differ for investment banks as subsidiaries of banking groups?}

Subsidiary banks as a part of a larger banking entity can benefit from liquidity injections as these banks have ready access to liquidity from the parent bank (Mayer and Carlyn, 2008). Banks that are members of a banking group can draw liquidity from the parent company in case of a financial shock (De Haas and van Lelyveld, 2010). We split the 
sample between banks that are part of a banking group and those which are not for this reason. Our findings are available in Tables 12 and 13.

\section{[INSERT TABLE 12\&13 ABOUT HERE]}

A number of previous studies have found a positive relationship between liquidity and bank performance (Bourke, 1989; Demirguc-Kunt and Huizinga, 1999; Athanasoglou et al., 2008). Our results show that for banks as part of a banking group, an increase in liquidity has a positive effect on efficiency at the $10 \%$ and $5 \%$ levels of significance (Model 1 and 2 in Table 12). Yet an increase in liquidity for stand-alone banks has a negative impact on efficiency at the 10\% and 5\% levels of significance (Model 3 and 4 in Table 12). The negative relationship between liquidity and bank performance is supported by empirical evidence (Kwan, 2003; Staikouras et al., 2008; Pasiouras and Kosmidou, 2007). The first result supports the 'bad luck hypothesis' ( $\left.\mathrm{H}_{2}\right)$ concerning the positive impact of liquidity on cost efficiency. However, our findings imply that the impact of liquidity on performance varies and depends on whether investment bank could draw liquidity from a larger banking entity. Table 13 presents threshold estimations for stand-alone banks, revealing that an increase in liquidity for the low liquidity regime banks has a negative effect on investment bank performance at the 5\% level of significance as $\lambda=-0.086$ (Model 1 in Table 13). Moreover, threshold estimation for subsidiary banks shows that for both the low and high regime investment banks there exists a negative relationship between efficiency and liquidity but the coefficients are not statistically different from zero (Model 2 in Table 13). The results for both banking groups may indicate that our significant threshold liquidity effects for the whole sample are driven by banks with low liquidity that are mainly banks that do not belong to a larger banking entity.

Table 14 shows that the majority of stand-alone investment banks fall within the low liquidity regime. Lastly, the number of banks in the low liquidity regime decreases markedly (20\%) from 2007 to 2008 with the burst of the financial crisis (Panel A in Table 14).

\section{[INSERT TABLE 14 ABOUT HERE]}

\section{Conclusions}

In this paper we employ the dynamic panel threshold methodology introduced by Kremer et al. (2013) and find that the positive impact of Z-Score on investment bank performance, as measured by cost efficiency, is more pronounced for banks with lower risk. This result is important in the context of the investment banks whose operations 
are inherently riskier than those of conventional banks (Bertay et al., 2013). Furthermore, we find that liquidity has a negative impact on cost efficiency for banks that belong to the low liquidity regime. This effect is driven for the most part by standalone banks that could neither draw liquidity from a larger banking entity nor rely on deposits as commercial banks (Gatev and Strahan, 2006; Gatev et al., 2009). The analysis also reveals that the fee-income ratio has a positive impact on cost efficiency only for banks belonging to the low fee-income regime. This suggests that an increase in investment banking fees comes at the expense of increased risk for investment banks in the high fee-income regime. This is a major difference between investment banks and conventional, as for the latter a rise of the fee-income could bring diversification benefits (De-Young and Rice, 2004; Chiorazzo et al., 2008).

Notably, we find important changes in the percentages of banks that fall within each threshold regime before and during the financial crisis. In particular, the percentage of banks in the regime of high default risk (low Z-Score), increases considerably in the 2008-2010 period. This indicates that investment banks underwent a period of substantial financial distress. Moreover, the number of banks belonging to the low liquidity regime increases in the years of the crisis. This, in combination with the negative impact of liquidity on cost efficiency for stand-alone investment banks in the low liquidity regime could denote the high costs of drawing liquidity during financial turmoil (Brunnermeier and Pedersen, 2009). Finally, there is a slight increase in the number of banks belonging to the low fee-income regime over the crisis period. The positive impact of fee-income on the performance of banks in the low regime could suggest the importance of income generation capability in order to weather the financial crisis.

Measures to strengthen bank stability are warranted. One of the regulatory gaps revealed by the credit crunch was the absence of strict capital adequacy ratios for investment banks. This became evident during the crisis period as the intensification of investment banking risk led to significant losses both for the financial institutions and the entire economy. More stringent legislation related to capital requirements such as the Dodd-Frank Act (2010) in the US and the Capital Requirements Directive 4 (CRD 4) in Europe could act as defence mechanism against default risk and thus improve investment bank performance. In terms of liquidity, the liquidity coverage ratio (LCR) proposed in Basel III and in CRD 4 could ensure sufficient short-term liquidity and thus 
diminish the need of banks to seek external funding during periods of financial turmoil. The LCR measure could be of particular importance for stand-alone investment banks who cannot rely on deposit funding.

\section{References}

Abu-Bader, S., and Abu-Qarn, A. (2008). Financial development and economic growth: the Egyptian experience. Journal of Policy Modelling, 30, pages 887-898.

Acharya, V., Hasan, I., and Saunders, A. (2006). Should Banks be Diversified? Evidence from Individual Bank Portfolios. Journal of Business, 79, pages 1355-412.

Adrian, T., and Shin, H. (2010). Liquidity and leverage. Journal of Financial Intermediation, 19, pages 418-437.

Adrian, T., and Shin, H. (2008). Financial intermediaries, financial stability, and monetary policy. FRB of New York staff report No.346, pages 1-37.

Adrian, T., and Shin, H. (2009). Money, liquidity, and monetary policy. The American Economic Review, 99, pages 600-605.

Allen, F., and Carletti, E. (2010). An Overview of the Crisis: Causes, Consequences, and Solutions. International Review of Finance, 10, pages 1-26.

Allen, L., and Rai, A. (1996). Operational Efficiency in banking: An international comparison. Journal of Banking and Finance, 20, pages 655-672. 
Altunbas, Y., and Marques, D. (2008). Mergers and Acquisitions and Bank Performance in Europe: The Role of Strategic Similarities, Journal of Economics and Business, 60, pages 204-22.

Altunbas, Y., Ming-Hau L., Molyneux P., and Seth R. (2000). Efficiency and risk in Japanese banking. Journal of Banking and Finance, 24, pages 1605-1628.

Arellano, M., and Bond, S. (1991). Some tests of specification for panel data: Monte Carlo evidence and an application to employment equations. The Review of Economic Studies, 58, pages 277-297.

Arellano, M., and Bover, O. (1995). Another look at the instrumental-variable estimation of error components models. Journal of Econometrics, 68, pages 29-52.

Athanasoglou, P., Brissimis, S., and Delis, M. (2008). Bank specific, industry specific and macroeconomic determinants of bank profitability. Journal of International Financial Markets, Institutions and Money, 18, pages 121-136.

Baglioni, A., Beccalli, E., Boitani, A., and Monticini, A. (2013). Is the leverage of European banks procyclical?. Empirical Economics, 45, pages 1251-1266.

Bao, J., and Edmans A. (2011). Do investment banks matter for M\&A returns? Review of Financial Studies, 24, pages 2286-2315.

Barry, T., Lepetit, L., and Tarazi, A. (2011). Ownership structure and risk in publicly held and privately owned banks. Journal of Banking and Finance, 35, pages 1327-1340.

Baxter, L. (2012). A Current Assessment of Some Extraterritorial Impacts of The DoddFrank Act with Special Focus on The Volcker Rule and Derivatives Regulation. Korean Journal of Banking and Financial Law, 5, pages 4-29.

Beatty, R., and Welch I. (1996). Issuer Expenses and Legal Liability in Initial Public Offerings, Journal of Law and Economics, 39, pages 545-602.

Beccalli, E. (2004). Cross- country comparisons of efficiency: Evidence from the UK and Italian investment firms. Journal of Banking and Finance, 28, pages 1363-1383.

Beccalli, E. (2007). Does IT investment improve bank performance? Evidence from Europe. Journal of Banking and Finance, 31, pages 2205-2230.

Beck, T., Demirguc-Kunt, A., and Maksimovic, V. (2004). Bank competition and access to finance: international evidence. Journal of Money, Credit, and Banking, 36, pages $627-648$.

Berger, N., and Mester, L. (1997). Inside the black box: What explains differrences in the efficiencies of financial institutions?. Journal of Banking and Finance, 21, pages 895-947.

Berger, N., and De-Young, R. (1997). Problem loans and cost efficiency in commercial banks. Journal of Banking and Finance, 21, pages 849-870.

Berger, N., and Humphrey, B. (1997). Efficiency of financial institutions: International survey and directions for future research. European Journal of Operational Research, 98, pages $175-212$. 
Berger, N., De-Young, R., Genay, H., and Udell, G. (2000). Globalization of financial institutions: Evidence from cross-border banking performance. Brookings-Wharton papers on financial services, 2000, pages 23-120.

Bertay, C., Demirguc-Kunt, A., and Huizinga, H. (2013). Do we need big banks? Evidence on performance, strategy and market discipline. Journal of Financial Intermediation, 22, pages 532-558.

Bick, A. (2007). Pitfalls in panel threshold models: The role of regime dependent intercepts. Working Paper, Goethe University.

Blundell, R., and Bond, S. (1998). Initial conditions and moment restrictions in dynamic panel data models. Journal of Econometrics, 87, pages 115-143.

Bonin, J., Hasan, I., and Wachtel, P. (2005). Bank performance, efficiency and ownership in transition countries. Journal of Banking and Finance, 29, pages 31-53.

Bordo, D., and Jeanne, O. (2002). Boom-busts in asset prices, economic instability, and monetary policy. National Bureau of Economic Research No. w8966.

Bourke, P. (1989). Concentration and Other Determinants of Bank Profitability in Europe, North America and Australia. Journal of Banking and Finance, 13, pages 6579.

Boyd, J., and Graham, S. (1986). Risk, regulation, and bank holding company expansion into nonbanking. Federal Reserve Bank of Minneapolis, Quarterly Review, 10, pages 2-17.

Brissimis, S., Delis, M., and Papanikolaou, N. (2008). Exploring the nexus between banking sector reform and performance: Evidence from newly acceded EU countries. Journal of Banking and Finance, 32, pages 2674-2683.

Brunnermeier, M., and Pedersen, L. (2009). Market liquidity and funding liquidity. Review of Financial studies, 22, pages 2201-2238.

Brunnermeier, M. (2009). Deciphering the 2007-08 liquidity and credit crunch. Journal of Economic Perspectives, 23, pages 77-100.

Burgess, S. (2011). Measuring financial sector output and its contribution to UK GDP. Bank of England Quarterly Bulletin, 51, pages 234-246.

Caner, M., and Hansen, B. (2004). Instrumental variable estimation of a threshold model. Econometric Theory, 20, pages 813-843.

Caselli, S., Chiarella, C., Gatti, S., and Gigante, G. (2013). The Capital Markets for Italian Companies: A resource to re-launch the country and renew growth. University of Bocconi.

Chan, K. (1993). Consistency and limiting distribution of the least squares estimator of a threshold autoregressive model. Annals of Statistics, 21, pages 520-533.

Chiorazzo, V., Milani, C., and Salvini, F. (2008). Income diversification and bank performance: Evidence from Italian banks. Journal of Financial Services Research, 33, pages 181-203.

De Haas, R., and Van Lelyveld, I. (2010). Internal capital markets and lending by multinational bank subsidiaries. Journal of Financial Intermediation, 19, pages 1-25. 
Delis, M. (2012). Bank competition, financial reform, and institutions: The importance of being developed. Journal of Development Economics, 97, pages 450-465.

Demirguc-Kunt, A., and Huizinga, H. (1999). Determinants of Commercial Bank Interest Margins and Profitability: Some International Evidence. World Bank Economic Review, 13, pages 379-408.

Demirguc-Kunt, A., and Huizinga, H. (2010). Bank activity and funding strategies: the impact on risk and return. Journal of Financial Economics, 98, pages 626-650.

Demirguc-Kunt, A., and Maksimovic, V. (2002). Funding growth in bank-based and market-based financial systems: evidence from firm-level data. Journal of Financial Economics, 65, pages 337-363.

De-Young, R., and Roland, K. (2001). Product mix and earnings volatility at commercial banks: Evidence from a degree of total leverage model. Journal of Financial Intermediation, 10, pages 54-84.

De-Young, R., Rice, T. (2004). Non-interest income and financial performance at US commercial banks. Financial Review, 39, pages 101-127.

Dietsch, M., and Lozano-Vivas, A. (2000). How the environment determines banking efficiency: A comparison between French and Spanish industries. Journal of Banking and Finance, 24, pages 985-1004.

Dodd-Frank Wall Street Reform and Consumer Protection Act. (2010). Pub. L. No. 111-203, § 619, 24 Stat. 1376.

Eichengreen, B., Mody, A., Nedeljkovic, M., and Sarno, L. (2012). How the subprime crisis went global: Evidence from bank credit default swap spreads. Journal of International Money and Finance, 31, pages 1299-1318.

Fang, L. (2005). Investment bank reputation and the price and quality of underwriting services. Journal of Finance, 60, pages 2729-2761.

Fernando, C., May, A., and Megginson, W. (2012). The value of investment banking relationships: evidence from the collapse of Lehman Brothers. The Journal of Finance, 67, pages 235-270.

Fiordelisi F., Marques-Ibanez, D., and Molyneux, P. (2011). Efficiency and Risk in European Banking. Journal of Banking and Finance, 35, pages 1315-1326.

Fiordelisi, F., and Molyneux, P. (2010). The determinants of shareholder value in European banking. Journal of Banking and Finance, 34, pages 1189-1200.

Gambacorta, L., and Van Rixtel, A. (2013). Structural bank regulation initiatives: approaches and implications . Bank for International Settlements.

Gatev, E., Schuermann T., and Strahan P. (2009). Managing Banks Liquidity Risk: How Deposit-Loan Synergies Vary with Market Conditions. Review of Financial Studies, 22, pages 995-1020.

Gatev, E., Strahan P. (2006). Banks' Advantage in Hedging Liquidity Risk: Theory and Evidence from the Commercial Paper Market. Journal of Finance, 61, pages 867-892.

Gerdesmeier, D., Reimers, E., and Roffia, B. (2010). Asset Price Misalignments and the Role of Money and Credit. International Finance, 13, pages 377-407. 
Grammatikos, T., Saunders, A., and Swary, I. (1986). Returns and risks of US bank foreign currency activities. The Journal of Finance, 41, pages 671-682.

Hansen, B. (1997). Inference in TAR models. Studies in Nonlinear Dynamics and Econometrics, 2, pages 1-14.

Hansen, B. (1999). Threshold effects in non-dynamic panels: estimation, testing and inference. Journal of Econometrics, 93, pages 345-368.

Hunter, W., and Jagtiani, J. (2003). An analysis of advisor choice, fees, and effort in mergers and acquisitions. Review of Financial Economics, 12, pages 65-81.

Ismail, A. (2010). Are good financial advisors really good? The performance of investment banks in the M\&A market. Review of Quantitative Finance and Accounting, 35 , pages $411-429$.

Jensen, C., and Meckling, H. (1976). Theory of the firm: Managerial behavior, agency costs and ownership structure. Journal of Financial Economics, 3, pages 305-360.

Jondrow, J., Knox Lovell, A., Materov, S., and Schmidt, P. (1982). On the estimation of technical inefficiency in the stochastic frontier production function model. Journal of Econometrics, 19, pages 233-238.

Joyce, M., Lasaosa, A., Stevens, I., and Tong, M. (2011). The financial market impact of quantitative easing in the United Kingdom. International Journal of Central Banking, 7, pages 113-161.

Kalemli-Ozcan, S., Sorensen, B., and Yesiltas, S. (2012). Leverage across firms, banks, and countries. Journal of International Economics, 88, pages 284-298.

Kobayashi, T., Spiegel, M., and Yamori, N. (2006). Quantitative easing and Japanese bank equity values. Journal of the Japanese and International Economies, 20, pages 699-721.

Kolasinski, A., and Kothari, S. (2008). Investment banking and analyst objectivity: Evidence from analysts affiliated with mergers and acquisitions advisors. Journal of Financial and Quantitative Analysis, 43, pages 817-842.

Kremer, S., Bick, A., and Nautz, D. (2013). Inflation and growth: new evidence from a dynamic panel threshold analysis. Empirical Economics, 44, pages 861-878.

Krishnamurthy, A. (2009). How debt markets have malfunctioned in the crisis. National Bureau of Economic Research No. w15542.

Kwan, S. (2003). Operating performance of banks among Asian economies: An international and time series comparison. Journal of Banking and Finance, 27, pages 471-489.

Laeven, L., and Levine, R. (2007). Is there a diversification discount in financial conglomerates?. Journal of Financial Economics, 85, pages 331-367.

Lensink, R., Meesters, A., and Naaborg, I. (2008). Bank efficiency and foreign ownership: Do good institutions matter?. Journal of Banking and Finance, 32, pages 834-844.

Lepetit, L., Nys, E., Rous, P., and Tarazi, A. (2008). Bank income structure and risk: an empirical analysis of European banks. Journal of Banking and Finance, 32, pages $1452-1467$. 
Levine, R. (1997). Financial Development and Economic Growth: Views and Agenda. Journal of Economic Literature, 35, pages 688-726.

Liikanen, E. (2012). High-level Expert Group on reforming the structure of the EU banking sector. Final report.

Lin, Y. (2009) The impact of the financial crisis on developing countries. Text of a lecture delivered at Korea Development Institute, Seoul, 31 October.

Lin, X., and Zhang, Y. (2009). Bank Ownership Reform and Bank Performance in China. Journal of Banking and Finance, 33, pages 20-29.

Lozano-Vivas, A., and Pasiouras, F. (2010). The impact of non-traditional activities on the estimation of bank efficiency: international evidence. Journal of Banking and Finance, 34, pages 1436-1449.

Lyonnet, V., and Werner, R. (2012). Lessons from the Bank of England on quantitative easing and other unconventional monetary policies. International Review of Financial Analysis, 25, pages 94-105.

Martin, C., and Milas, C. (2012). Quantitative easing: a sceptical survey. Oxford Review of Economic Policy, 28, pages 750-764.

Maudos, J., and Guevara, J. (2007). The cost of market power in banking: social welfare loss vs. cost inefficiency. Journal of Banking and Finance, 31, pages 21032125 .

Maudos, J., and Solis, L. (2009). The determinants of net interest income in the Mexican banking system: an integrated model. Journal of Banking and Finance, 33, pages 1920-1931.

Mayer, C., and Carlin, W. (2008). Multinational Ownership and Subsidiary Investment. Working paper.

Merciera, S., Schaeck K., and Wolfe S. (2007). Small European banks: Benefits from diversification?. Journal of Banking and Finance, 31, pages 1975-98.

Micco, A., Panizza, U., and Yanez, M. (2007). Bank ownership and performance. Does politics matter?. Journal of Banking and Finance, 31, pages 219-241.

Miller, M., and Noulas, G. (1997). Portfolio mix and large-bank profitability in the USA. Applied Economics, 29, pages 505-512.

Morana, C. (2008). International stock markets co-movements: the role of economic and financial integration. Empirical Economics, 35, pages 333-359.

Morgan, D., and Stiroh, K. (2001). Market discipline of banks: The asset test. Journal of Financial Services Research, 20, pages 195-208.

Myers, C. (1977). Determinants of corporate borrowing. Journal of Financial Economics, 5, pages 147-175.

Pasiouras, F. (2008). International evidence on the impact of regulations and supervision on banks' technical efficiency: an application of two-stage data envelopment analysis. Review of Quantitative Finance and Accounting, 30, pages 187223.

Pasiouras, F., and Kosmidou, K. (2007). Factors influencing the profitability of domestic and foreign commercial banks in the European Union. Research in International Business and Finance, 21, pages 222-237. 
Radic, N., Fiordelisi, F., and Girardone, C. (2012). Efficiency and Risk-taking in Precrisis Investment Banks. Journal of Financial Services Research, 41, pages 81-101.

Rau, P. (2000). Investment bank market share, contingent fee payments, and the performance of acquiring firms. Journal of Financial Economics, 56, pages 293-324.

Reichlin, L. (2013). Monetary policy and banks in the euro area: the tale of two crises. Journal of Macroeconomics, 39, pages 387-340.

Roodman, D. (2006). How to do xtabond2: An introduction to difference and system GMM in Stata. Center for Global Development. Working paper No.103.

Schroder, M., Borell, M., Gropp, R., Iliewa, Z., Jaroszek, L., Lang, G., Schmidt, S., Trela, K. (2012). The role of investment banking for the German economy: Final report for Deutsche Bank AG No. 12-01.

Sealey, J., and Lindley, J. (1977). Inputs, Outputs, and Theory of Production and Cost of Depository Financial Institutions. The Journal of Finance, 32, pages 1251-1266.

Shandre, M., and James, A. (2004). Financial development and economic growth in Australia: An Empirical Analysis. Empirical Economics, 29, pages 247-260.

Staikouras, C., Mamatzakis, E., and Koutsomanoli- Filippaki, A. (2008). Cost efficiency of the banking industry in the South Eastern European region. Journal of International Financial Markets, Institutions and Money, 18, pages 483-497.

Stiroh, K. (2004). Diversification in banking: Is noninterest income the answer?. Journal of Money, Credit, and Banking, 36, pages 853-882.

Stowell, D. (2012). Investment Banks, Hedge Funds, and Private Equity. Academic Press.

Swiss Bankers Association and The Boston Consulting Group (2011). Summary: Banking in transition - future prospects for banking in Switzerland.

Thomson Reuters, (2007). Global Investment Banking Review. Various issues.

Thomson Reuters, (2012). Global Investment Banking Review. Various issues.

Thomson Reuters, (2013). Global Investment Banking Review. Various issues.

Tomljanovich, M., and Ying, Y. (2005). We're all connected: business cycle synchronizationinG7countries.URL:http://academics.hamilton.edu/economics/home/ marc_t.pdf.

Vander, V. (2002). Cost and Profit Efficiency of Financial Conglomerates and Universal Banks in Europe. Journal of Money, Credit and Banking, 34, pages 254-282.

Vickers, J., and Lagarde, C. (2013). Banking reform in Britain and Europe. Various issues.

Vinals, J., and Moghadam R. (2012). Financial System Stability Assessment. International Monetary Fund France.

Voutsinas, K., and Werner, R. (2011a). Credit supply and corporate capital structure: Evidence from Japan. International Review of Financial Analysis, 20, pages 320-334. 
Voutsinas, K., and Werner, R. (2011b). New evidence on the effectiveness of Quantitative Easing in Japan. CFS working paper No. 2011/30.

Werner, R. (1995). How to create a recovery through 'Quantitative Monetary Easing'. The Nihon Keizai Shinbun (Nikkei), page 1-26.

Whaley, E. (2000). The investor fear gauge. Journal of Portfolio Management, 26, pages $12-17$.

Wheelock, D., and Wilson, P. (2000). Why do banks disappear? The determinants of US bank failures and acquisitions. Review of Economics and Statistics, 82, pages 127138.

Windmeijer, F. (2005). A finite sample correction for the variance of linear efficient two-step GMM estimators. Journal of Econometrics, 126, pages 25-51. 


\section{List of Tables}

Table 1. Descriptive statistics of the variables employed in the cost frontier estimations.

\begin{tabular}{cccccc}
\hline Variable & Description & Mean & Stand. Deviation & Minimum & Maximum \\
\hline $\mathrm{TC}$ & Total Cost & 1,688 & 5,142 & 0.0019 & 59,100 \\
$\mathrm{Y}_{1}$ & Total Earnings assets & 71,800 & 224,000 & 0.0033 & 2590,000 \\
$\mathrm{Y}_{2}$ & Investment Banking Fees & 0.999 & 2,694 & 0.0001 & 23,700 \\
$\mathrm{~N}_{1}$ & Equity & 1,698 & 4,354 & 0.0011 & 50,100 \\
$\mathrm{~N}_{2}$ & Assets & 37,700 & 0,361 & 0.0033 & 3,444 \\
$\mathrm{P}_{1}$ & Price of labour & 0.776 & 3.222 & 0.0002 & 1.8 \\
$\mathrm{P}_{2}$ & Price of physical capital & 27.54 & 160.82 & 0.0667 & 2072.00 \\
\hline
\end{tabular}

Notes: the Table reports the variables used in the cost frontier estimation for the period 1997-2010. Total Cost (TC): personnel, interest and non-interest expenses; Outputs $\left(\mathrm{Y}_{1} \& \mathrm{Y}_{2}\right)$ ); Total Earning assets (loans, deposits from banks and credit institutions, government securities, derivatives and other earning assets) and 2) Investment Banking Fees (net fees, commission and trading income); $\mathrm{Netputs}^{\left(\mathrm{N}_{1}\right.}$ \& $\left.\mathrm{N}_{2}\right)$ ) Equity and 2) Total Assets; Inputs $\left(\mathrm{P}_{1} \& \mathrm{P}_{2}\right)$ ) Price of labour (personnel expenses over total assets) and 2) Price of physical capital (total operating expenses over fixed assets). The values of TC, $\mathrm{N}_{1}, \mathrm{~N}_{2}, \mathrm{Y}_{1}$ and $\mathrm{Y}_{2}$, are in million dollars, while $\mathrm{P}_{1}$ and $\mathrm{P}_{2}$ are ratios.

Table 2. Descriptive statistics of bank-specific and country-level variable.

\begin{tabular}{|c|c|c|c|c|c|c|c|c|c|c|c|c|c|}
\hline Country & $\mathrm{N}$ & $\begin{array}{c}\text { Z- } \\
\text { Score }\end{array}$ & $\begin{array}{c}\text { Invest. } \\
\text { Banking } \\
\text { Fees/ } \\
\text { TA }\end{array}$ & Liquid./TA & E/TA & $\begin{array}{l}\text { Income } \\
\text { Divers. }\end{array}$ & $\begin{array}{c}\text { Securities } \\
\text { /TA }\end{array}$ & $\begin{array}{l}\text { GDP } \\
\text { per } \\
\text { capita }\end{array}$ & $\begin{array}{c}\text { FDI } \\
\text { Inflows }\end{array}$ & $\begin{array}{c}\text { FDI } \\
\text { Outflows }\end{array}$ & $\begin{array}{c}\text { House } \\
\text { Price } \\
\text { Index }\end{array}$ & $\begin{array}{l}\text { Stock } \\
\text { Price } \\
\text { Index }\end{array}$ & Reserves \\
\hline Canada & 17 & 2.0823 & 0.0342 & 0.523 & 0.0547 & -0.1807 & 0.6517 & 10.1286 & 3.58 & 3.914 & 152.41 & 155.38 & 24.2956 \\
\hline France & 63 & 1.2827 & 0.0556 & 0.3548 & 0.1055 & 0.242 & 0.2039 & 10.027 & 2.733 & 5.249 & 196.15 & 147.60 & 24.3474 \\
\hline Germany & 122 & 1.9408 & 0.1702 & 0.2146 & 0.2709 & 0.4383 & 0.6112 & 10.0852 & 1.885 & 2.864 & 94.89 & 134.53 & 24.666 \\
\hline Italy & 23 & 1.4954 & 0.0167 & 0.306 & 0.0919 & -0.384 & 0.2018 & 9.8863 & 1 & 2.386 & 194.96 & 122.82 & 24.2341 \\
\hline Japan & 141 & 0.6568 & 0.1131 & 0.4957 & 0.2872 & 0.1012 & 0.2755 & 10.5545 & 0.177 & 1.096 & 74.96 & 83.04 & 27.272 \\
\hline Switz. & 21 & 1.9423 & 0.0431 & 0.6277 & 0.0606 & 0.4901 & 0.2143 & 10.4944 & 4.689 & 10.384 & 113.66 & 107.11 & 24.6329 \\
\hline UK & 176 & 2.346 & 0.0695 & 0.3525 & 0.1576 & 0.3306 & 0.2644 & 10.2306 & 4.62 & 5.384 & 259.73 & 107.01 & 24.4951 \\
\hline US & 143 & 2.262 & 0.1954 & 0.3908 & 0.1912 & 0.207 & 0.5225 & 10.5004 & 1.666 & 1.867 & 167.98 & 135.83 & 24.964 \\
\hline Total & 706 & & & & & & & & & & & & \\
\hline Mean & & 1.751 & 0.0872 & 0.4081 & 0.1524 & 0.1556 & 0.3682 & 10.2384 & 2.544 & 4.143 & 156.84 & 124.16 & 24.8633 \\
\hline
\end{tabular}

Notes: the Table reports descriptive statistics of bank-specific and most of country level variables used to perform fixed effect and dynamic panel regressions. $\mathrm{N}$ stands for the number of observations by country. As bank-specific variables we use: Z-Score $=(1+\mathrm{ROE}) /(\mathrm{Standard}$ Deviation of $\mathrm{ROE})$; Invest. Banking Fees/TA= net fees, commission and net trading income over total assets; Liquid assets over total assets; E/TA= equity over total assets; Income divers.= (1- |Net Interest Income-Other Operating Income $) /$ Total Operating Income; Securities/TA= total securities over total assets. Some of the country level independent variables that we use are: GDP per capita (natural logarithm); FDI inflows (natural logarithm); FDI outflows (natural logarithm); House Price Index; Stock Price Index; Reserves (natural logarithm). For bank-specific variables we use FITCH Bankscope database while for most country variables we use World Development indicators from World Bank. As House Price Index we use the index constructed by the Economist Intelligence Unit using as the base year the 1997. For the Stock Price Index data we use Bloomberg database. 
Table 3. Descriptive Statistics of cost efficiency (1997-2010).

\begin{tabular}{lcccc}
\hline \multicolumn{1}{c}{ Country } & Mean & Standard Deviation & Minimum & Maximum \\
\hline Canada & 0.4946 & 0.1690 & 0.1848 & 0.7473 \\
France & 0.5859 & 0.1817 & 0.1543 & 0.8582 \\
Germany & 0.7769 & 0.1320 & 0.1767 & 0.9170 \\
Italy & 0.6547 & 0.1426 & 0.4508 & 0.8812 \\
Japan & 0.9197 & 0.0282 & 0.7230 & 0.9559 \\
Switz. & 0.8557 & 0.0893 & 0.6718 & 0.9622 \\
UK & 0.6029 & 0.1658 & 0.2099 & 0.9451 \\
US & 0.6319 & 0.1484 & 0.2247 & 0.8373 \\
\hline Mean & $\mathbf{0 . 6 9 0 3}$ & $\mathbf{0 . 1 3 2 1}$ & $\mathbf{0 . 1 7 6 7}$ & $\mathbf{0 . 9 6 2 1}$ \\
\hline
\end{tabular}

Notes: the Table reports the mean efficiencies for the G7 and Switzerland over the period 1997-2010. Efficiencies are derived from the Stochastic Frontier Analysis (SFA) . 
Table 4. Fixed effects results for Z-Score, liquidity and investment banking fees as bank cost efficiency determinants in the G7 and Switzerland (1997-2010).

\begin{tabular}{|c|c|c|c|c|}
\hline Variables & Model(1) & $\operatorname{Model}(2)$ & $\operatorname{Model}(3)$ & Model(4) \\
\hline Z-Score & $\begin{array}{l}0.008 * * \\
(0.0039)\end{array}$ & & & $\begin{array}{l}0.009 * * \\
(0.0038)\end{array}$ \\
\hline Investment Banking Fees/TA & & $\begin{array}{c}0.128 \\
(0.0885)\end{array}$ & & $\begin{array}{c}0.144 * \\
(0.0852)\end{array}$ \\
\hline Liquid assets/TA & & & $\begin{array}{c}0.048 \\
(0.0327)\end{array}$ & $\begin{array}{l}0.069 * * \\
(0.0307)\end{array}$ \\
\hline $\mathrm{E} / \mathrm{TA}$ & $\begin{array}{c}0.119 * * \\
(0.0586)\end{array}$ & $\begin{array}{c}0.106^{*} \\
(0.0590)\end{array}$ & $\begin{array}{c}0.108 * \\
(0.0595)\end{array}$ & $\begin{array}{c}0.111^{*} \\
(0.0611)\end{array}$ \\
\hline Securities/TA & $\begin{array}{c}0.172 * * * \\
(0.0418)\end{array}$ & $\begin{array}{c}0.182 * * * \\
(0.0447)\end{array}$ & $\begin{array}{c}0.170 * * * \\
(0.0407)\end{array}$ & $\begin{array}{c}0.204 * * * \\
(0.0420)\end{array}$ \\
\hline Income diversification & $\begin{array}{c}-0.016 * * * \\
(0.0018)\end{array}$ & $\begin{array}{c}-0.015 * * * \\
(0.0018)\end{array}$ & $\begin{array}{c}-0.015^{* * *} \\
(0.0018)\end{array}$ & $\begin{array}{c}-0.016 * * * \\
(0.0019)\end{array}$ \\
\hline GDP per capita & $\begin{array}{c}-0.032 \\
(0.156)\end{array}$ & $\begin{array}{c}-0.039 \\
(0.154)\end{array}$ & $\begin{array}{c}0.001 \\
(0.155)\end{array}$ & $\begin{array}{c}-0.058 \\
(0.152)\end{array}$ \\
\hline FDI inflows & $\begin{array}{c}-0.008 * * * \\
(0.0027)\end{array}$ & $\begin{array}{c}-0.008 * * * \\
(0.0027)\end{array}$ & $\begin{array}{c}-0.008 * * * \\
(0.0026)\end{array}$ & $\begin{array}{c}-0.008 * * * \\
(0.0026)\end{array}$ \\
\hline FDI outflows & $\begin{array}{c}-0.002 \\
(0.0019)\end{array}$ & $\begin{array}{c}-0.002 \\
(0.0019)\end{array}$ & $\begin{array}{c}-0.002 \\
(0.0019)\end{array}$ & $\begin{array}{l}-0.003 * \\
(0.0018)\end{array}$ \\
\hline DCPS/GDP & $\begin{array}{c}-0.013 \\
(0.0315)\end{array}$ & $\begin{array}{c}-0.012 \\
(0.0315)\end{array}$ & $\begin{array}{c}-0.010 \\
(0.0311)\end{array}$ & $\begin{array}{c}-0.010 \\
(0.0319)\end{array}$ \\
\hline Real effective exchange rate & $\begin{array}{c}-0.000 \\
(0.0006)\end{array}$ & $\begin{array}{c}-0.000 \\
(0.0006)\end{array}$ & $\begin{array}{r}4.14 \mathrm{e}-05 \\
(0.0007)\end{array}$ & $\begin{array}{c}-5.74 \mathrm{e}-05 \\
(0.0006)\end{array}$ \\
\hline House Price Index & $\begin{array}{l}-0.0003 \\
(0.0002)\end{array}$ & $\begin{array}{l}-0.0003 \\
(0.0002)\end{array}$ & $\begin{array}{l}-0.0003 \\
(0.0002)\end{array}$ & $\begin{array}{c}-0.0005^{*} \\
(0.0002)\end{array}$ \\
\hline Stock Price Index & $\begin{array}{c}-0.0007 * * \\
(0.0003)\end{array}$ & $\begin{array}{c}-0.0006^{* *} \\
(0.0003)\end{array}$ & $\begin{array}{l}-0.0006 * \\
(0.0003)\end{array}$ & $\begin{array}{c}-0.0006 * * \\
(0.0003)\end{array}$ \\
\hline Burst of the asset bubble (dummy) & $\begin{array}{c}-0.0252 * * \\
(0.0103)\end{array}$ & $\begin{array}{c}-0.0239 * * \\
(0.0101)\end{array}$ & $\begin{array}{c}-0.0225 * * \\
(0.0104)\end{array}$ & $\begin{array}{c}-0.0245 * * \\
(0.0101)\end{array}$ \\
\hline Reserves & $\begin{array}{l}0.046^{* *} \\
(0.0193)\end{array}$ & $\begin{array}{l}0.048 * * \\
(0.0189)\end{array}$ & $\begin{array}{l}0.044 * * \\
(0.0187)\end{array}$ & $\begin{array}{l}0.045^{* *} \\
(0.0183)\end{array}$ \\
\hline Volatility Implied Index & $\begin{array}{c}-0.002 * * * \\
(0.0005)\end{array}$ & $\begin{array}{c}-0.002 * * * \\
(0.0005)\end{array}$ & $\begin{array}{c}-0.002 * * * \\
(0.0006)\end{array}$ & $\begin{array}{c}-0.002 * * * \\
(0.0005)\end{array}$ \\
\hline Constant & $\begin{array}{c}0.0343 \\
(1.529)\end{array}$ & $\begin{array}{c}0.0293 \\
(1.508)\end{array}$ & $\begin{array}{c}-0.303 \\
(1.500)\end{array}$ & $\begin{array}{c}0.238 \\
(1.477)\end{array}$ \\
\hline F-test & $11.68 * * *$ & $10.46 * * *$ & $11.75 * * *$ & $11.31 * * *$ \\
\hline Observations & 706 & 706 & 706 & 706 \\
\hline R-squared & 0.185 & 0.190 & 0.183 & 0.206 \\
\hline Number of banks & 97 & 97 & 97 & 97 \\
\hline
\end{tabular}

Notes: the Table reports the regression results based on a fixed effect model over the period 1997 to 2010 . The dependent variable is cost efficiency derived using a SFA methodology. As bank-specific independent variables we employ: ZScore $=(1+\mathrm{ROE}) /($ Standard Deviation of ROE $)$; Investment Banking Fees $=$ net fees, commission and trading income over total assets; Liquid assets over total assets; E/TA= equity over total assets; Income diversification= 1- |Net Interest Income-Other Operating Income//Total Operating Income; Securities/TA= total securities over total assets. As country variables we employ: GDP per capita; DCPS/GDP; FDI inflows; FDI outflows; Real Effective Exchange Rate; House price Index; Stock Price Index; Burst of the asset bubble (dummy); Reserves (natural logarithm); Volatility Implied Index. For bank-specific variables we use FITCH Bankscope database while for most country variables we use World Development indicators from World Bank. As House Price Index we use the index constructed by the Economist Intelligence Unit using as the base year the 1997. For Volatility Implied Index (VIX-Chicago Board Options Exchange Volatility Index) and Stock Price Index we use Bloomberg database. To avoid collinearity problems with the selected variables, we first analyze correlations of all the selected variables. We check that there is not a high level of correlation between the variables used in the models. ***,** and * indicate $1 \%, 5 \%$ and $10 \%$ significance levels respectively. Robust Standard errors are in parentheses. 
Table 5. Dynamic panel results for Z-Score, liquidity and investment banking fees as bank cost efficiency determinants in the G7 and Switzerland (1997-2010).

\begin{tabular}{|c|c|c|c|c|}
\hline Variables & Model(1) & Model(2) & Model(3) & Model(4) \\
\hline Lag efficiency & $\begin{array}{c}0.371 * * * \\
(0.116)\end{array}$ & $\begin{array}{l}0.459 * * * \\
(0.105)\end{array}$ & $\begin{array}{c}0.425^{* * *} * \\
(0.104)\end{array}$ & $\begin{array}{c}0.278 * * * \\
(0.0874)\end{array}$ \\
\hline Z-Score & $\begin{array}{l}0.013 * * \\
(0.0056)\end{array}$ & & & $\begin{array}{c}0.0152 * * \\
(0.0069)\end{array}$ \\
\hline Investment Banking Fees/TA & & $\begin{array}{l}0.128 * * \\
(0.0541)\end{array}$ & & $\begin{array}{l}0.116 * * \\
(0.0489)\end{array}$ \\
\hline Liquid assets/TA & & & $\begin{array}{c}0.0679 \\
(0.0553)\end{array}$ & $\begin{array}{c}0.0813 \\
(0.0605)\end{array}$ \\
\hline $\mathrm{E} / \mathrm{TA}$ & $\begin{array}{c}-0.0765 \\
(0.0786)\end{array}$ & $\begin{array}{c}-0.138^{*} \\
(0.0714)\end{array}$ & $\begin{array}{c}-0.037 \\
(0.0988)\end{array}$ & $\begin{array}{c}0.018 \\
(0.0807)\end{array}$ \\
\hline Securities/TA & $\begin{array}{c}0.164 * * * \\
(0.0536)\end{array}$ & $\begin{array}{c}0.153 * * * \\
(0.0406)\end{array}$ & $\begin{array}{c}0.190 * * * \\
(0.0650)\end{array}$ & $\begin{array}{c}0.228 * * * \\
(0.0585)\end{array}$ \\
\hline Income diversification & $\begin{array}{c}-0.023 * * * \\
(0.0026)\end{array}$ & $\begin{array}{c}-0.022 * * * \\
(0.0024)\end{array}$ & $\begin{array}{c}-0.024 * * * \\
(0.0041)\end{array}$ & $\begin{array}{c}-0.025 * * * \\
(0.0041)\end{array}$ \\
\hline GDP per capita & $\begin{array}{l}-0.211 \\
(0.180)\end{array}$ & $\begin{array}{l}-0.175 \\
(0.145)\end{array}$ & $\begin{array}{l}-0.240^{*} \\
(0.140)\end{array}$ & $\begin{array}{l}-0.262 \\
(0.200)\end{array}$ \\
\hline FDI inflows & $\begin{array}{c}-0.006^{* * *} \\
(0.002)\end{array}$ & $\begin{array}{l}-0.007 * * \\
(0.0024)\end{array}$ & $\begin{array}{l}-0.006 * * \\
(0.0025)\end{array}$ & $\begin{array}{l}-0.006 * * \\
(0.0023)\end{array}$ \\
\hline FDI outflows & $\begin{array}{c}0.000 \\
(0.00192)\end{array}$ & $\begin{array}{c}-0.000 \\
(0.00164)\end{array}$ & $\begin{array}{c}-0.002 \\
(0.00160)\end{array}$ & $\begin{array}{c}-0.001 \\
(0.00201)\end{array}$ \\
\hline DCPS/GDP & $\begin{array}{c}-0.103 * * \\
(0.0435)\end{array}$ & $\begin{array}{c}-0.0732 * \\
(0.0418)\end{array}$ & $\begin{array}{l}-0.0629 \\
(0.0524)\end{array}$ & $\begin{array}{c}-0.0828 * \\
(0.0464)\end{array}$ \\
\hline Real effective exchange rate & $\begin{array}{l}4.63 e-05 \\
(0.0008)\end{array}$ & $\begin{array}{c}0.000276 \\
(0.0007)\end{array}$ & $\begin{array}{l}0.000547 \\
(0.0008)\end{array}$ & $\begin{array}{l}2.90 \mathrm{e}-05 \\
(0.0009)\end{array}$ \\
\hline House Price Index & $\begin{array}{c}-0.0006 * * \\
(0.0002)\end{array}$ & $\begin{array}{c}-0.0006 * * * \\
(0.0002)\end{array}$ & $\begin{array}{c}-0.0005^{* *} \\
(0.0002)\end{array}$ & $\begin{array}{l}-0.0005^{*} \\
(0.0003)\end{array}$ \\
\hline Stock Price Index & $\begin{array}{l}-0.001 * * \\
(0.0002)\end{array}$ & $\begin{array}{c}-0.001 * * \\
(0.0002)\end{array}$ & $\begin{array}{c}-0.000 \\
(0.0002)\end{array}$ & $\begin{array}{l}-0.001 * * \\
(0.0002)\end{array}$ \\
\hline Burst of the asset bubble (dummy) & $\begin{array}{c}-0.016 \\
(0.0119)\end{array}$ & $\begin{array}{c}-0.015 \\
(0.0105)\end{array}$ & $\begin{array}{c}-0.005 \\
(0.0140)\end{array}$ & $\begin{array}{c}-0.016 \\
(0.0175)\end{array}$ \\
\hline Reserves & $\begin{array}{l}0.042 * * \\
(0.0196)\end{array}$ & $\begin{array}{c}0.0453 * * \\
(0.0183)\end{array}$ & $\begin{array}{c}0.063 * * * \\
(0.0209)\end{array}$ & $\begin{array}{c}0.062 * * * \\
(0.0183)\end{array}$ \\
\hline Volatility Implied Index & $\begin{array}{c}-0.001 \\
(0.0006)\end{array}$ & $\begin{array}{c}-0.000 \\
(0.0006)\end{array}$ & $\begin{array}{c}-0.000 \\
(0.0007)\end{array}$ & $\begin{array}{c}-0.001 \\
(0.0006)\end{array}$ \\
\hline Constant & $\begin{array}{c}1.859 \\
(2.034)\end{array}$ & $\begin{array}{c}1.272 \\
(1.700)\end{array}$ & $\begin{array}{c}1.387 \\
(1.514)\end{array}$ & $\begin{array}{c}1.796 \\
(1.978)\end{array}$ \\
\hline Wald test & $230.17 * * *$ & $354.73 * * *$ & $317.36 * * *$ & $203.56 * * *$ \\
\hline Sargan (p-value) & $43.5(0.19)$ & $39.22(0.29)$ & $38.89(0.31)$ & $73.78(0.45)$ \\
\hline $\operatorname{AR}(1)$ & $-2.4202 * *$ & $-2.773 * * *$ & $-2.9819 * * *$ & $2.4062 * * *$ \\
\hline $\operatorname{AR}(2)$ & -0.9097 & -1.0944 & -1.044 & 0.9080 \\
\hline Observations & 609 & 609 & 609 & 609 \\
\hline Number of instruments & 45 & 45 & 45 & 89 \\
\hline Number of banks & 97 & 97 & 97 & 97 \\
\hline \multicolumn{5}{|c|}{$\begin{array}{l}\text { Notes: the Table reports the dynamic panel regression results for the period } 1997 \text { to } 2010 \text {. As bank-specific independent } \\
\text { variables we employ: Z-Score= (1+ROE)/ (Standard Deviation of ROE); Investment Banking Fees=Net fees, commission and } \\
\text { trading income over total assets; Liquid assets over total assets; E/TA: equity over total assets; Income diversification=1- |Net } \\
\text { Interest Income-Other Operating Income//Total Operating Income; Securities /TA=total securities over total assets. As } \\
\text { country variables we employ: GDP per capita; DCPS/GDP; FDI inflows; FDI outflows; Real Effective Exchange Rate; House } \\
\text { price Index; Stock Price Index; Burst of the asset bubble (dummy); Reserves (natural logarithm); Volatility Implied Index. } \\
\text { For bank-specific variables we use FITCH Bankscope database while for most country variables we use World Development } \\
\text { indicators from World Bank. As House Price Index we use the index constructed by the Economist Intelligence Unit using as } \\
\text { the base year the } 1997 \text {. For Volatility Implied Index (Chicago Board Options Exchange Volatility Index) and Stock Price } \\
\text { Index we use Bloomberg database. To avoid collinearity problems with the selected variables, we first analyze correlations of } \\
\text { all the selected variables. We check that there is not a high level of correlation between the variables used in the models. ***, } \\
* * \text { and } * \text { indicate } 1 \%, 5 \% \text { and } 10 \% \text { significance levels respectively. Windmeijer (2005) corrected (robust) standard errors are } \\
\text { in parentheses. }\end{array}$} \\
\hline
\end{tabular}


Table 6.Results of dynamic panel threshold estimation with Z-Score as threshold variable.

\begin{tabular}{lcr}
\hline \multicolumn{3}{c}{ Investment banks } \\
\hline \hline Threshold estimate & & \\
\hline Z-Score & & 1.516866 \\
95\% confidence interval & & S.E \\
\hline \hline Impact of Z-Score & $0.012^{* * *}$ & 0.0058 \\
\hline$\lambda 1$ & $0.044^{* * *}$ & 0.0180 \\
$\lambda 2$ & & S.E \\
\hline \hline Impact of covariates & 0.056 & 0.0861 \\
\hline Investment Banking Fees/TA & 0.056 & 0.0372 \\
Liquid Assets/TA & $0.108^{* * *}$ & 0.0403 \\
E/TA & $0.190^{* * *}$ & 0.0370 \\
Securities/TA & $-0.016^{* * *}$ & 0.0040 \\
Income diversification & -0.015 & 0.1274 \\
GDP per capita & $-0.008^{* * *}$ & 0.0025 \\
FDI inflows & -0.003 & 0.0018 \\
FDI outflows & -0.001 & 0.0284 \\
DCPS/GDP & 0.000 & 0.0006 \\
Real Effective Exchange Rate & $-0.000^{* * *}$ & 0.0002 \\
House Price Index & $-0.001^{* *}$ & 0.0002 \\
Stock Price Index & $-0.024^{* * *}$ & 0.0103 \\
Burst of the asset bubble (dummy) & $0.041^{* * *}$ & 0.0132 \\
Reserves & $-0.002^{* * *}$ & 0.0005 \\
Volatility Implied Index & $0.018^{* * *}$ & 0.0055 \\
$\delta$ & 609 & \\
\hline Observations & 372 & \\
Low regime & 237 & \\
High regime & & \\
\hline
\end{tabular}

Notes: the Table reports the estimations for the dynamic panel threshold model. Each regime has at least 5\% of the observations (Hansen, 1999). The threshold value of Z-Score variable for banks range between 1.31883 and 2.1656. We denote as dependent variable banks' efficiency scores $\left(e f f_{i t}\right)$, while as the threshold and the regime dependent variable we impose the $\left(Z-\right.$ Score $\left._{i t}\right)$ which represents banks' default risk. Following Bick (2007), the model accounts for regime dependent intercepts $(\delta)$. We assume $m_{i t}$ includes bank-specific and country explanatory variables. For bank-specific variables we use: Investment Banking Fees= net fees, commission and trading income over total assets; Liquid assets over total assets; Securities/TA= total securities over total assets; Income diversification= $1-\mid$ Net Interest Income-Other Operating Income//Total Operating Income; E/TA= equity over total assets. As country variables we employ: GDP per capita; DCPS/GDP; FDI inflows; FDI outflows; Real Effective Exchange Rate; House price Index; Stock Price Index; Burst of the asset bubble (dummy); Reserves (natural logarithm); Volatility Implied Index. For bank-specific variable we use FITCH Bankscope database while for most country variables we use World Development indicators from World Bank. As House Price Index we use the index constructed by the Economist Intelligence Unit using as the base year the 1997. For Volatility Implied Index (Chicago Board Options Exchange Volatility Index) we use Bloomberg database. Also as endogenous variable for the model we impose the Investment Banking Fees, where Investment Banking Fees $=$ eff $f_{i t-1}$. We check that there is not a high level of correlation between the variables used in the models. ***, ** and * indicate 1\%, 5\% and $10 \%$ significance levels respectively.

Table 7. Dynamic Threshold Analysis: classification of investment banks into the two identified regimes based on threshold value of Z-Score.

\begin{tabular}{|c|c|c|c|c|c|c|c|c|c|c|c|c|c|}
\hline \multicolumn{14}{|c|}{ Threshold: Z-Score } \\
\hline & 1998 & 1999 & 2000 & 2001 & 2002 & 2003 & 2004 & 2005 & 2006 & 2007 & 2008 & 2009 & 2010 \\
\hline Low regime & $64 \%$ & $47 \%$ & $53 \%$ & $75 \%$ & $78 \%$ & $82 \%$ & $62 \%$ & $49 \%$ & $52 \%$ & $52 \%$ & $54 \%$ & $65 \%$ & $67 \%$ \\
\hline High regime & $36 \%$ & $53 \%$ & $47 \%$ & $25 \%$ & $22 \%$ & $18 \%$ & $38 \%$ & $51 \%$ & $48 \%$ & $48 \%$ & $46 \%$ & $35 \%$ & $33 \%$ \\
\hline
\end{tabular}

Notes: the Table shows the classification of the investment banks based on the Z-Score threshold value that we obtained following Kremer's et al. (2013) threshold model for dynamic panel. As threshold variable we use: Z-Score $=(1+\mathrm{ROE}) /(\mathrm{Standard}$ Diversification ROE). 
Table 8. Results of dynamic panel threshold estimation with liquidity as threshold variable.

\begin{tabular}{|c|c|c|}
\hline \multicolumn{3}{|c|}{ Investment banks } \\
\hline Threshold estimate & & \\
\hline Liquidity & & 0.229967 \\
\hline $95 \%$ confidence interval & & $(0.02045-0.59454)$ \\
\hline Impact of Liquid Assets/TA & & S.E \\
\hline$\lambda 1$ & $-0.202 * *$ & 0.0907 \\
\hline$\lambda 2$ & 0.017 & 0.0313 \\
\hline Impact of covariates & & S.E \\
\hline Z-Score & 0.005 & 0.0053 \\
\hline Investment Banking Fees/TA & $0.141 * * *$ & 0.0676 \\
\hline $\mathrm{E} / \mathrm{TA}$ & $0.113 * *$ & 0.0405 \\
\hline Securities/TA & $0.199 * * *$ & 0.0377 \\
\hline Income diversification & $-0.017 * * *$ & 0.0043 \\
\hline GDP per capita & -0.047 & 0.1237 \\
\hline FDI inflows & $-0.008 * * *$ & 0.0025 \\
\hline FDI outflows & $-0.003 *$ & 0.0018 \\
\hline DCPS/GDP & -0.004 & 0.0290 \\
\hline Real Effective Exchange Rate & 0.000 & 0.0006 \\
\hline House Price Index & $-0.000^{*}$ & 0.0002 \\
\hline Stock Price Index & $-0.001 * *$ & 0.0002 \\
\hline Burst of the asset bubble (dummy) & $-0.024 * *$ & 0.0099 \\
\hline Reserves & $0.045^{* * *}$ & 0.0131 \\
\hline Volatility Implied Index & $-0.002 * * *$ & 0.0005 \\
\hline$\delta$ & 0.049 & 0.0514 \\
\hline Observations & 609 & \\
\hline Low regime & 195 & \\
\hline High regime & 414 & \\
\hline
\end{tabular}

Notes: the Table reports the estimations for the dynamic panel threshold model. Each regime has at least 5\% of the observations (Hansen, 1999). The liquidity threshold value ranges between 0.02045 and 0.59454 . We denote as dependent variable banks' efficiency scores $\left(e f f_{i t}\right)$, while as the threshold and the regime dependent variable we impose the liquidity (liquidity $y_{i t}$ ), which represents bank's liquid assets over total assets. Following Bick (2007), the model accounts for regime dependent intercepts $(\delta)$. We assume $m_{i t}$ includes bank-specific and country explanatory variables. For bank-specific variables we use: Z-Score $=(1+\mathrm{ROE}) /($ Standard Deviation of ROE); Investment Banking Fees $=$ net fees, commission and trading income over total assets; Securities $/ \mathrm{TA}=$ total securities over total assets; Income diversification= 1- |Net Interest Income-Other Operating Income//Total Operating Income; E/TA= equity over total assets. As country variables we employ: GDP per capita; DCPS/GDP; FDI inflows; FDI outflows; Real Effective Exchange Rate; House price Index; Stock Price Index; Reserves (natural logarithm); Burst of the asset bubble (dummy); Volatility Implied Index . For bank-specific variables we use FITCH Bankscope database while for most country variables we use World Development indicators from World Bank. As House Price Index we use the index constructed by the Economist Intelligence Unit using as the base year the 1997. For Volatility Implied Index (VIX-Chicago Board Options Exchange Volatility Index) and Stock Price Index we use Bloomberg database. Also as endogenous variable for the model we impose Z-Score, where $Z-S$ core $=$ eff $f_{i t-1}$. We check that there is not a high level of correlation between the variables used in the models. ${ }^{* *}, *^{*}$ and $*$ indicate $1 \%, 5 \%$ and $10 \%$ significance levels respectively.

Table 9. Dynamic Threshold Analysis: classification of investment banks into the two identified regimes based on threshold value of Liquidity.

\begin{tabular}{|c|c|c|c|c|c|c|c|c|c|c|c|c|c|}
\hline \multicolumn{14}{|c|}{ Threshold: Liquidity } \\
\hline & 1998 & 1999 & 2000 & 2001 & 2002 & 2003 & 2004 & 2005 & 2006 & 2007 & 2008 & 2009 & 2010 \\
\hline Low regime & $45 \%$ & $41 \%$ & $31 \%$ & $21 \%$ & $22 \%$ & $32 \%$ & $29 \%$ & $38 \%$ & $32 \%$ & $28 \%$ & $36 \%$ & $37 \%$ & $30 \%$ \\
\hline High regime & $55 \%$ & $59 \%$ & $69 \%$ & $79 \%$ & $78 \%$ & $68 \%$ & $71 \%$ & $63 \%$ & $68 \%$ & $72 \%$ & $64 \%$ & $63 \%$ & $70 \%$ \\
\hline
\end{tabular}

Notes: the Table shows the classification of the investment banks based on the liquidity threshold value that we obtained following

Kremer's et al. (2013) threshold model for dynamic panel. As threshold variable we use the ratio of liquid assets over total assets. 
Table 10. Results of dynamic panel threshold estimation with investment banking fees as threshold variable.

\begin{tabular}{lcr}
\hline & Investment banks & \\
\hline \hline Threshold estimate & & 0.009322 \\
\hline Investment banking fees & & $0.008271-0.009322)$ \\
95\% confidence interval & & S.E \\
\hline \hline Impact of investment banking fees/TA & $0.216^{* *}$ & 0.0941 \\
\hline$\lambda 1$ & -0.005 & 0.0633 \\
$\lambda 2$ & & S.E \\
\hline \hline Impact of covariates & 0.007 & 0.0052 \\
\hline Z-Score & 0.059 & 0.0366 \\
Liquid Assets/TA & $0.117^{* *}$ & 0.0414 \\
E/TA & 0.020 & 0.0352 \\
Securities/TA & $-0.016^{* * *}$ & 0.0040 \\
Income diversification & -0.113 & 0.1261 \\
GDP per capita & $-0.009^{* * *}$ & 0.0026 \\
FDI inflows & -0.003 & 0.0017 \\
FDI outflows & -0.027 & 0.0286 \\
DCPS/GDP & 0.000 & 0.0006 \\
Real Effective Exchange Rate & 0.000 & 0.0002 \\
House Price Index & $-0.001 * *$ & 0.0002 \\
Stock Price Index & $-0.026^{* *}$ & 0.0097 \\
Burst of the asset bubble (dummy) & $0.046^{* * *}$ & 0.0134 \\
Reserves & $-0.002^{* * *}$ & 0.0005 \\
Volatility Implied Index & $0.146^{* *}$ & 0.0672 \\
\hline Observations & 609 & 73 \\
Low regime & 533 & \\
High regime & & \\
\hline
\end{tabular}

Notes: the Table reports the estimations for the dynamic panel threshold model. Each regime has at least 5\% of the observations (Hansen, 1999). The threshold value of Investment Banking Fees variable for banks range between 0.008271 and 0.009322 . We denote as dependent variable banks' efficiency scores $\left(e f f_{i t}\right)$, while as the threshold and the regime dependent variable we impose the Investment Banking Fees (Investment Banking Fees ${ }_{i t}$ ), which represents banks' net fees commission and trading income over total assets. Following Bick (2007), the model accounts for regime dependent intercepts $(\delta)$. We assume $m_{i t}$ includes bank-specific and country explanatory variables. For bank-specific variables we use: Z-Score $=(1+\mathrm{ROE}) /($ Standard Deviation of ROE); Liquid assets over total assets; Securities/TA= total securities over total assets; Income diversification= 1- |Net Interest Income-Other Operating Income//Total Operating Income; E/TA= equity over total assets. As country variables we employ: GDP per capita; DCPS/GDP; FDI inflows; FDI outflows; Real Effective Exchange Rate; House price Index; Stock Price Index; Burst of the asset bubble (dummy); Reserves (natural logarithm) ; Volatility Implied Index. For bank-specific variables we use FITCH Bankscope database while for most country variables we use World Development indicators from World Bank. As House Price Index we use the index constructed by the Economist Intelligence Unit using as the base year the 1997. For Volatility Implied Index (VIX-Chicago Board Options Exchange Volatility Index) and Stock Price Index we use Bloomberg database.. Also as endogenous variable for the model we impose Z-Score, where $Z-$ Score $=e f f_{i t-1}$. We check that there is not a high level of correlation between the variables used in the models. $* * *, * *$ and $*$ indicate $1 \%, 5 \%$ and $10 \%$ significance levels respectively.

Table 11. Dynamic Threshold Analysis: classification of investment banks into the two identified two regimes based on Investment Banking Fees.

\begin{tabular}{|c|c|c|c|c|c|c|c|c|c|c|c|c|c|}
\hline \multicolumn{14}{|c|}{ Threshold: Investment Banking Fees } \\
\hline & 1998 & 1999 & 2000 & 2001 & 2002 & 2003 & 2004 & 2005 & 2006 & 2007 & 2008 & 2009 & 2010 \\
\hline Low regime & $5 \%$ & $6 \%$ & $6 \%$ & $6 \%$ & $6 \%$ & $11 \%$ & $10 \%$ & $13 \%$ & $12 \%$ & $15 \%$ & $19 \%$ & $15 \%$ & $14 \%$ \\
\hline High regime & $95 \%$ & $94 \%$ & $94 \%$ & $94 \%$ & $94 \%$ & $89 \%$ & $90 \%$ & $88 \%$ & $88 \%$ & $85 \%$ & $81 \%$ & $85 \%$ & $86 \%$ \\
\hline
\end{tabular}

Notes: the Table shows the classification of the investment banks based on the investment banking fees threshold value that we obtained following Kremer's et al. (2013) threshold model for dynamic panel. As threshold variable we use: Investment Banking Fees= net fees, commission and net trading income over total assets. 
Table 12. Sensitivity analysis with liquidity as bank cost efficiency determinant. Models $1 \& 2$ refer to dynamic panel results for banks that belong to a group and Models $3 \& 4$ for stand-alone investment banks.

\begin{tabular}{|c|c|c|c|c|}
\hline Variables & Model(1) & Model(2) & Model(3) & Model(4) \\
\hline Lag efficiency & $\begin{array}{c}0.434 * * * \\
(0.0993)\end{array}$ & $\begin{array}{c}0.491 * * * \\
(0.119)\end{array}$ & $\begin{array}{c}0.355^{* * * *} \\
(0.172)\end{array}$ & $\begin{array}{l}0.223^{*} \\
(0.176)\end{array}$ \\
\hline Liquid assets/TA & $\begin{array}{c}0.105^{*} \\
(0.0645)\end{array}$ & $\begin{array}{l}0.147 * * \\
(0.0707)\end{array}$ & $\begin{array}{l}-0.103^{*} \\
(0.0652)\end{array}$ & $\begin{array}{c}-0.087 * * \\
(0.0430)\end{array}$ \\
\hline Z-Score & & $\begin{array}{c}0.015^{*} \\
(0.0076)\end{array}$ & & $\begin{array}{l}0.081 * * \\
(0.0036)\end{array}$ \\
\hline Investment banking fees/TA & & $\begin{array}{c}0.388 * * * \\
(0.145)\end{array}$ & & $\begin{array}{c}0.096 \\
(0.091)\end{array}$ \\
\hline $\mathrm{E} / \mathrm{TA}$ & $\begin{array}{l}-0.136 \\
(0.120)\end{array}$ & $\begin{array}{r}-0.179 \\
(0.132)\end{array}$ & $\begin{array}{c}0.043 \\
(0.079)\end{array}$ & $\begin{array}{l}-0.002 \\
(0.011)\end{array}$ \\
\hline Securities/TA & $\begin{array}{c}0.244 * * * \\
(0.0629)\end{array}$ & $\begin{array}{c}0.272 * * * \\
(0.0592)\end{array}$ & $\begin{array}{c}0.079^{*} \\
(0.0472)\end{array}$ & $\begin{array}{l}0.211^{* *} \\
(0.0831)\end{array}$ \\
\hline Income diversification & $\begin{array}{c}-0.021 * * * \\
(0.0022)\end{array}$ & $\begin{array}{c}-0.023^{* * *} \\
(0.0019)\end{array}$ & $\begin{array}{c}-0.102 * * * \\
(0.0333)\end{array}$ & $\begin{array}{c}-0.102 * * * \\
(0.0394)\end{array}$ \\
\hline GDP per capita & $\begin{array}{l}-0.290 \\
(0.178)\end{array}$ & $\begin{array}{c}-0.473 * * * \\
(0.172)\end{array}$ & $\begin{array}{c}-0.006 \\
(0.0319)\end{array}$ & $\begin{array}{l}-0.008 \\
(0.295)\end{array}$ \\
\hline FDI inflows & $\begin{array}{c}-0.009 * * \\
(0.0038)\end{array}$ & $\begin{array}{c}-0.008 * * * \\
(0.0029)\end{array}$ & $\begin{array}{c}-0.004 \\
(0.0049)\end{array}$ & $\begin{array}{c}-0.006 * * \\
(0.003)\end{array}$ \\
\hline FDI outflows & $\begin{array}{c}0.001 \\
(0.0019)\end{array}$ & $\begin{array}{c}0.002 \\
(0.00241)\end{array}$ & $\begin{array}{c}-0.002 \\
(0.0025)\end{array}$ & $\begin{array}{c}-0.002 \\
(0.0015)\end{array}$ \\
\hline DCPS/GDP & $\begin{array}{c}-0.086 * * \\
(0.041)\end{array}$ & $\begin{array}{c}-0.067 \\
(0.0444)\end{array}$ & $\begin{array}{l}-0.093 \\
(0.107)\end{array}$ & $\begin{array}{l}-0.190 \\
(0.11)\end{array}$ \\
\hline Real effective exchange rate & $\begin{array}{c}0.001 \\
(0.0012)\end{array}$ & $\begin{array}{c}0.001 \\
(0.0011)\end{array}$ & $\begin{array}{c}-1.39 \mathrm{e}-06 \\
(0.0018)\end{array}$ & $\begin{array}{c}0.001 \\
(0.0013)\end{array}$ \\
\hline House Price Index & $\begin{array}{c}-0.001 * * \\
(0.0002)\end{array}$ & $\begin{array}{l}-0.001 * \\
(0.0002)\end{array}$ & $\begin{array}{c}-0.000 \\
(0.0004)\end{array}$ & $\begin{array}{c}-0.001 \\
(0.0005)\end{array}$ \\
\hline Stock Price Index & $\begin{array}{l}-0.0006 \\
(0.0004)\end{array}$ & $\begin{array}{l}-0.0005 \\
(0.0004)\end{array}$ & $\begin{array}{l}-0.0075^{*} \\
(0.0003)\end{array}$ & $\begin{array}{c}-0.0006 * * \\
(0.0003)\end{array}$ \\
\hline Burst of the asset bubble (dummy) & $\begin{array}{c}-0.023 \\
(0.0159)\end{array}$ & $\begin{array}{c}-0.020 \\
(0.0194)\end{array}$ & $\begin{array}{c}0.019 \\
(0.0139)\end{array}$ & $\begin{array}{c}0.009 \\
(0.017)\end{array}$ \\
\hline Reserves & $\begin{array}{c}0.084 * * * \\
(0.0283)\end{array}$ & $\begin{array}{c}0.051^{*} \\
(0.0280)\end{array}$ & $\begin{array}{c}0.067 * \\
(0.0367)\end{array}$ & $\begin{array}{l}0.061 * * \\
(0.0308)\end{array}$ \\
\hline Volatility Implied Index & $\begin{array}{c}-0.001 \\
(0.001)\end{array}$ & $\begin{array}{c}0.001 \\
(0.0012)\end{array}$ & $\begin{array}{c}-7.19 \mathrm{e}-05 \\
(0.0007)\end{array}$ & $\begin{array}{c}0.000347 \\
(0.0008)\end{array}$ \\
\hline Constant & $\begin{array}{c}1.471 \\
(1.958)\end{array}$ & $\begin{array}{c}4.003 * * \\
(1.700)\end{array}$ & $\begin{array}{l}-0.187 \\
(3.938)\end{array}$ & $\begin{array}{l}-1.001 \\
(3.005)\end{array}$ \\
\hline Wald test & $365.63 * * *$ & $1058.80 * * *$ & $110.82 * * *$ & $194.33 * * *$ \\
\hline Sargan (p-value) & $36.98(0.35)$ & $21.25(0.45)$ & $18.65(0.52)$ & $18.73(0.56)$ \\
\hline $\operatorname{AR}(1)$ & $-2.42 * *$ & $-2.13^{* *}$ & $-2.12 * *$ & $-2.22 * *$ \\
\hline $\operatorname{AR}(2)$ & -1.156 & -0.81851 & 1.1053 & 1.13 \\
\hline Observations & 390 & 390 & 219 & 219 \\
\hline Number of instruments & 23 & 23 & 23 & 23 \\
\hline Number of banks & 64 & 64 & 33 & 33 \\
\hline
\end{tabular}

Notes: the Table reports the regression results based on a fixed effect model over the period 1997 to 2010 . The dependent variable is cost efficiency derived using a SFA methodology. As bank-specific independent variables we employ: ZScore $=(1+\mathrm{ROE}) /($ Standard Deviation of ROE $)$; Investment Banking Fees $=$ net fees, commission and trading income over total assets; Liquid assets over total assets; E/TA= equity over total assets; Income diversification= 1- Net Interest Income-Other Operating Income//Total Operating Income; Securities/TA= total securities over total assets. As country variables we employ: GDP per capita; DCPS/GDP; FDI inflows; FDI outflows; Real Effective Exchange Rate; House price Index; Stock Price Index; Burst of the asset bubble (dummy); Reserves (natural logarithm); Volatility Implied Index. For bank-specific variables we use FITCH Bankscope database while for most country variables we use World Development indicators from World Bank. As House Price Index we use the index constructed by the Economist Intelligence Unit using as the base year the 1997. For Volatility Implied Index (VIX-Chicago Board Options Exchange Volatility Index) and Stock Price Index we use Bloomberg database. Windmeijer (2005) corrected (robust) standard errors are in parentheses. 
Table 13. Sensitivity analysis with liquidity as threshold variable. Model 1 refers to dynamic panel threshold results for stand-alone banks and Model 2 for investment banks that belong to a group.

\begin{tabular}{lcc}
\hline & Investment banks & \\
\hline & & \\
Threshold estimate & Model $(1)$ & Model (2) \\
\hline Liquidity & 0.525295 & 0.314819 \\
95\% confidence interval & & \\
\hline \hline Impact of Liquid Assets/TA & $0.289233-0.557692)$ & -0.105 \\
\hline$\lambda 1$ & $-0.086^{* *}$ & -0.032 \\
$\lambda 2$ & -0.008 & \\
\hline \hline Impact of covariates & & 0.0068 \\
\hline Z-Score & $0.004^{*}$ & 0.1040 \\
Investment Banking Fees/TA & 0.018 & 0.0630 \\
E/TA & $0.106^{* * *}$ & $0.0420^{* * *}$ \\
Securities/TA & 0.041 & $-0.0155^{* * *}$ \\
Income diversification & $-0.099^{* * *}$ & 0.1523 \\
GDP per capita & $-0.448^{* * *}$ & $-0.0150^{* *}$ \\
FDI inflows & -0.001 & -0.0013 \\
FDI outflows & -0.001 & -0.0071 \\
DCPS/GDP & -0.014 & 0.0003 \\
Real Effective Exchange Rate & 0.000 & $-0.0006^{* *}$ \\
House Price Index & $-0.001 *$ & $-0.0008^{* *}$ \\
Stock Price Index & -0.000 & $-0.0331^{* *}$ \\
Burst of the asset bubble(dummy) & -0.011 & $0.0400^{* *}$ \\
Reserves & 0.068 & $-0.0025^{* * *}$ \\
Volatility Implied Index & -0.000 & 0.0022 \\
\hline Observations & 0.005 & 253 \\
\hline Low regime & 219 & 137 \\
High regime & 160 & 59 \\
\hline Tes: the Tabe & & \\
\hline
\end{tabular}

Notes: the Table reports the estimations for the dynamic panel threshold model. Each regime has at least 5\% of the observations (Hansen, 1999). The liquidity threshold value for non-banking group ranges between 0.289233 and 0.557693 while for banking group banks between 0.02081 and 0.541402 . We denote as dependent variable banks' efficiency scores $\left(e f f_{i t}\right)$, while as the threshold and the regime dependent variable we impose the liquidity (liquidity $_{i t}$ ), which represents bank's liquid assets over total assets. Following Bick (2007), the model accounts for regime dependent intercepts $(\delta)$. We assume $m_{i t}$ includes bank-specific and country explanatory variables. For bankspecific variables we use: Z-Score $=(1+\mathrm{ROE}) /($ Standard Deviation of ROE $)$; Investment Banking Fees= net fees, commission and trading income over total assets; Securities/TA= total securities over total assets; Income diversification= $1-\mid$ Net Interest Income-Other Operating Income//Total Operating Income; E/TA= equity over total assets. As country variables we employ: GDP per capita; DCPS/GDP; FDI inflows; FDI outflows; Real Effective Exchange Rate; House price Index; Stock Price Index; Burst of the asset bubble (dummy); Reserves (natural logarithm); Volatility Implied Index. For bank-specific variables we use FITCH Bankscope database while for most country variables we use World Development indicators from World Bank. As House Price Index we use the index constructed by the Economist Intelligence Unit using as the base year the 1997. For Volatility Implied Index (VIXChicago Board Options Exchange Volatility Index) and Stock Price Index we use Bloomberg database. Also as endogenous variable for the model we impose Z-Score, where $Z-S c o r e=e f f_{i t-1}$. We check that there is not a high level of correlation between the variables used in the models. $* * * * *$ and $*$ indicate $1 \%, 5 \%$ and $10 \%$ significance levels respectively. 
Table 14. Dynamic Threshold Analysis: classification of investment banks into the two identified regimes based on liquidity (stand-alone and group-banks).

\begin{tabular}{|c|c|c|c|c|c|c|c|c|c|c|c|c|c|}
\hline \multicolumn{14}{|c|}{$\begin{array}{l}\text { Panel A: Liquidity } \\
\text { (stand-alone banks) }\end{array}$} \\
\hline & 1998 & 1999 & 2000 & 2001 & 2002 & 2003 & 2004 & 2005 & 2006 & 2007 & 2008 & 2009 & 2010 \\
\hline Low regime & $73 \%$ & $77 \%$ & $79 \%$ & $74 \%$ & $62 \%$ & $80 \%$ & $71 \%$ & $77 \%$ & $77 \%$ & $80 \%$ & $60 \%$ & $67 \%$ & $63 \%$ \\
\hline High regime & $27 \%$ & $23 \%$ & $21 \%$ & $26 \%$ & $38 \%$ & $20 \%$ & $29 \%$ & $23 \%$ & $23 \%$ & $20 \%$ & $40 \%$ & $33 \%$ & $37 \%$ \\
\hline \multicolumn{14}{|c|}{$\begin{array}{l}\text { Panel B: Liquidity } \\
\text { (group-banks) }\end{array}$} \\
\hline & 1998 & 1999 & 2000 & 2001 & 2002 & 2003 & 2004 & 2005 & 2006 & 2007 & 2008 & 2009 & 2010 \\
\hline Low regime & $55 \%$ & $47 \%$ & $32 \%$ & $28 \%$ & $28 \%$ & $38 \%$ & $33 \%$ & $44 \%$ & $43 \%$ & $36 \%$ & $44 \%$ & $41 \%$ & $37 \%$ \\
\hline High regime & $45 \%$ & $53 \%$ & $68 \%$ & $72 \%$ & $72 \%$ & $62 \%$ & $67 \%$ & $56 \%$ & $57 \%$ & $64 \%$ & $56 \%$ & $59 \%$ & $63 \%$ \\
\hline \multicolumn{14}{|c|}{$\begin{array}{l}\text { Notes: the Table shows the classification of the investment banks (stand-alone and group-banks) based on the threshold values that } \\
\text { we obtained following Kremer's et al. (2013) threshold model for dynamic panel. As threshold variable we use the ratio of liquid } \\
\text { assets over total assets. The low regime stands for the percentage of banks that have bank-specific values for the liquidity measure } \\
\text { below the threshold, while the high regime stands for the percentages of banks that have bank-specific values above the liquidity } \\
\text { threshold value. }\end{array}$} \\
\hline
\end{tabular}




\section{List of Figures}

Figure 1.Number of issued shares of domestic companies (Domestic Market Capitalization

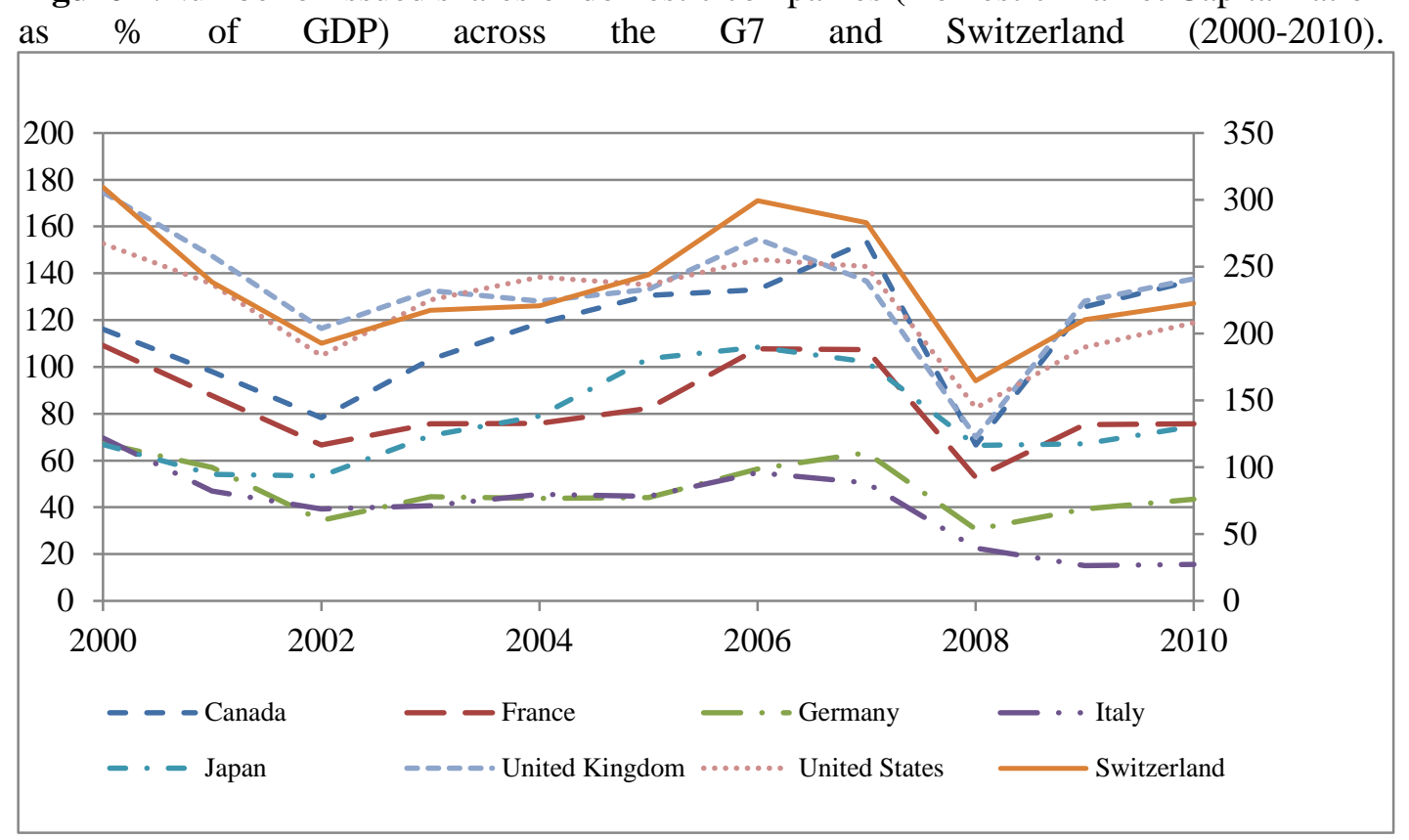

Notes: the Figure shows the Domestic Market Capitalization (as \% of GDP) across G7 and Switzerland countries (2000-2010). The left axis includes values that correspond to the US, the UK, France, Italy, Germany, Japan and Canada. The right axis includes only values that correspond to Switzerland. For Domestic Market Capitalization (as \% of GDP) data we use World Development indicators from the World Bank.

Figure 2. M\&A activity transaction value across the G7 and Switzerland (2000-2010).

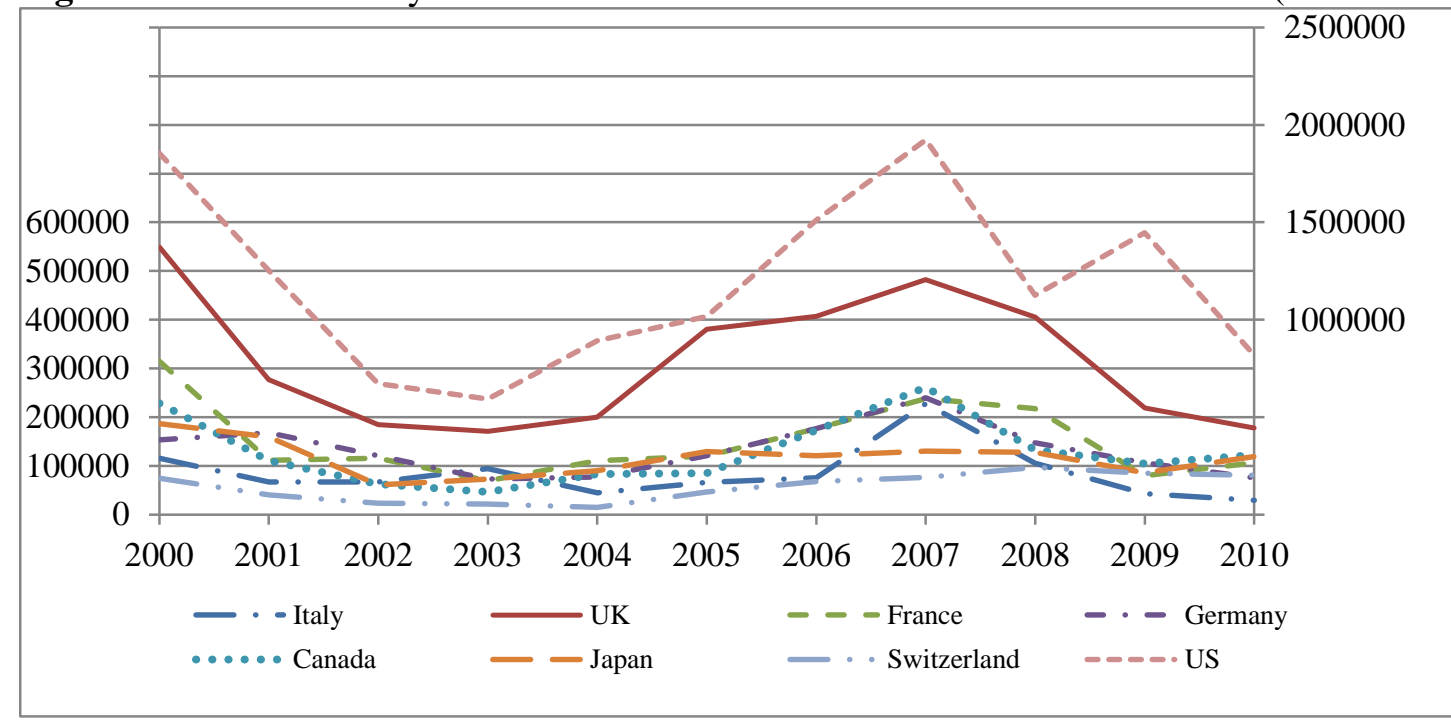

Notes: the Figure shows the M\&A transaction value in billion dollars across G7 and Switzerland (2000-2010). The left axis includes M\&A transaction values that correspond to the UK, France, Italy, Germany, Switzerland, Japan and Canada. The right axis stands for values that correspond to M\&A market in the US. For M\&A transaction value we use the Thomson One Banker database. 
Figure 3. Volatility Implied Index (VIX) over the 1997-2010 period.

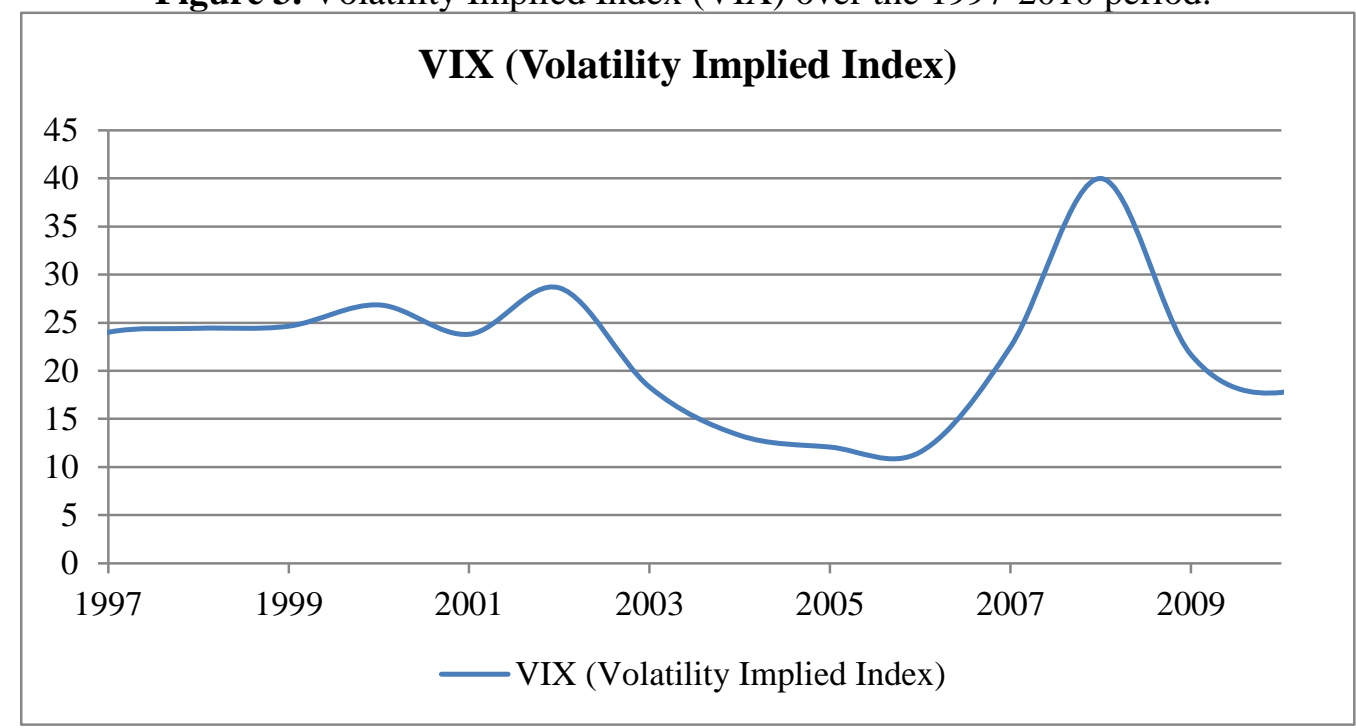

Notes: the Figure shows the average VIX (Chicago Board Options Exchange Volatility Index) over the period 1990-2012. Source: Bloomberg.

Figure 4. Mean efficiency score of investment banks over the 1997-2010 period.

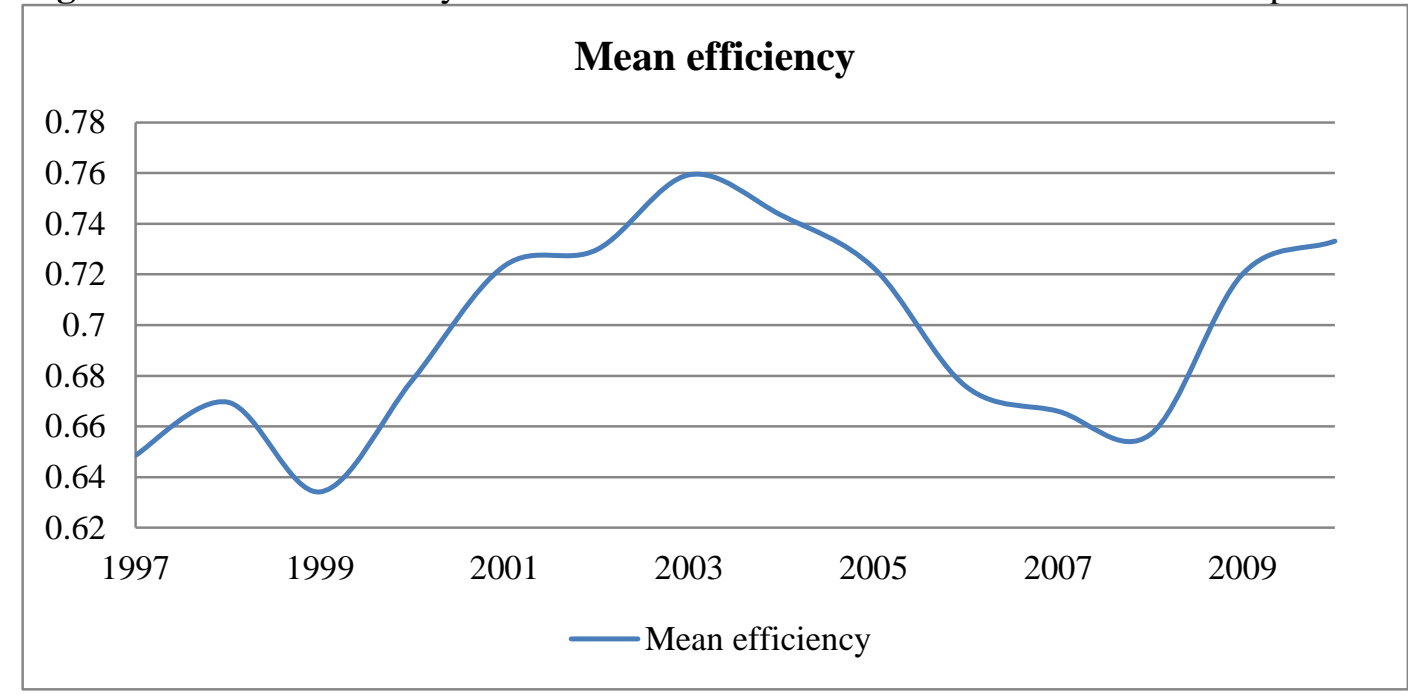

Notes: the Figure shows the average efficiency score of investment banks derived from Stochastic Frontier Analysis (SFA). 